\title{
Punitive Conditions of Prison Confinement: An Analysis of Pugh v. Locke and Federal Court Supervision of State Penal Administration under the Eighth Amendment
}

Ira P. Robbins

American University Washington College of Law, robbins@wcl.american.edu

Michael B. Buser

Follow this and additional works at: https://digitalcommons.wcl.american.edu/facsch_lawrev

Part of the Constitutional Law Commons, Courts Commons, Law Enforcement and Corrections Commons, and the Legal Remedies Commons

\section{Recommended Citation}

Ira P. Robbins \& Michael B. Buser, Punitive Conditions of Prison Confinement: An Analysis of Pugh v. Locke and Federal Court Supervision of State Penal Administration under the Eighth Amendment, 29 Stanford Law Review (1977).

Available at: https://digitalcommons.wcl.american.edu/facsch_lawrev/1742

This Article is brought to you for free and open access by the Scholarship \& Research at Digital Commons @ American University Washington College of Law. It has been accepted for inclusion in Articles in Law Reviews \& Other Academic Journals by an authorized administrator of Digital Commons @ American University Washington College of Law. For more information, please contact kclay@wcl.american.edu. 


\title{
Punitive Conditions of Prison
}

\section{Confinement: An Analysis of \\ Pugh v. Locke and Federal Court \\ Supervision of State Penal \\ Administration Under the \\ Eighth Amendment}

\author{
Ira P. Robbins* \\ Michael B. Buser**
}

The 1960's marked a watershed for the criminal justice system. ${ }^{1}$ In such areas as search and seizure, ${ }^{2}$ right to counsel ${ }^{3}$ and the privilege against self-incrimination, ${ }^{4}$ the federal courts first defined substantive constitutional rights and then imposed them upon disinclined functionaries at the state level. At first, these innovations raised thorny questions of constitutional interpretation about the rights involved, but, as is especially visible in the search and seizure area, the debate more recently has focused on the remedy' chosen by the Supreme Court for enforcing these rights against the states. ${ }^{5}$ This pattern of escalating federal involvement in the criminal

* A.B. 1970, University of Pennsylvania; J.D. I973, Harvard University. Associate Professor of Law, University of Kansas School of Law. Director, Kansas Defender Project.

** A.B. 1974, Georgetown University; J.D. 1977, University of Kansas.

I. Set L. Levy, Against the Law: The Nixon Court and Criminal Justice (r974). Sit gintrally A. Bickel, The Supreme Court and the Idea of Progress (1970); A. CoX, The Warren Court (1968); P. Kurland, Politics, the Constitution, and the WarREN COURT 74-82 (1970).

2. See, t.g., Chimel v. California, 395 U.S. 752 (1969); United States v. Katz, 389 U.S. 347 (1967); Mapp v. Ohio, 367 U.S. 643 (1961).

3. See, e.g., Johnson v. Avery, 393 U.S. 483 (1969); Escobedo v. Illinois, 378 U.S. 478 (I964); Jackson v. Denno, 378 U.S. 368 (1964); Gideon v. Wainwright, 372 U.S. 335 (1963).

4. See, e.g., Miranda v. Arizona, 384 U.S. 436 (Ig66); Malloy v. Hogan, 378 U.S. I (1964). Other important cases include Benton v. Maryland, 395 U.S. 784 (1969) (double jeopardy); Smith v. Hooey, 393 U.S. 374 (1969) (right to speedy trial); Duncan v. Louisiana, 39 I U.S. I45 (1968) (right to jury trial); Bruton v. United States, 39I U.S. I 23 (I968) (confrontation of witnesses); In re Gault, 387 U.S. I (1967) (juvenile proceedings); Fay v. Noia, 372 U.S. 391 ( 1963 ) (habeas corpus).

5. Compare, e.g., Mapp v. Ohio, 367 U.S. 643 (1961) (the 14th amendment's due process guarantee requires that state law enforcement officials conform to the fourth amendment's requirement of reasonable searches and seizures, and state courts must use the exclusionary rule to enforce that guarantee), with Stone v. Powell, 428 U.S. 465 (1976), and United States v. Calandra, 4 r4 U.S. 338 (1974) (criticizing the efficacy and desirability of the exclusionary rule as a remedy for unconstitutional search and seizure). See generally Robbins \& Sanders, The Habeas Coppus Trilogy of I 963: How to Kill Two Thirds With One Stone, I5 AM. CRIM. L. REv. - (I977). 
justice system was not limited to criminal investigatory procedures and protection of the rights of the accused at trial. Breaking with prior law and practice ${ }^{6}$ federal courts also started reviewing individual prisoner petitions alleging violation of constitutional rights, and, by the end of the decade, they began intervening in the policies and affairs of state correctional facilities. ${ }^{7}$ In this area of criminal procedure as well as in those surrounding the investigatory and trial stages, the more controversial innovations have begun to shift from definition of the right to more detailed explication of the remedy required once a violation of the right has been found.

Pugh v. Locke, ${ }^{8}$ a recent decision of the Federal District Court for the Middle District of Alabama, exemplifies this new remedial activism on the part of the federal judiciary that results when the eighth amendment's prohibition against cruel and unusual punishment is given broad scope. ${ }^{9}$ Thus, Pugh's significance begins with its uniquely clear and expansive holding that the confinement conditions facing the aggregate prison population of a state could violate the eighth amendment. This extension of the constitutional mandate to cover overall conditions of confinement, coupled with the finding in Pugh that Alabama's prison system violated that mandate, required Chief Judge Johnson to enlarge the scope of the ultimate federal remedy for unconstitutional punishment. He ordered Alabama prison officials to conform to minutely detailed minimum constitutional standards for prison conditions, and he undertook to monitor the entire prison system to assure compliance. No prior federal court had involved itself so deeply in the administration of a state prison system.

Given the generally deplorable conditions in many correctional facilities in the United States, ${ }^{10}$ this development poses serious and

6. See text accompanying notes $42-45$ infra.

7. See, e.g., Jones v. Wittenberg, 330 F. Supp. 707 (N.D. Ohio I971), aff'd in part and revid in part, 460 F.2d 126 (2d Cir. 1972), cert. denied, 409 U.S. 885 (1972); Holt v. Sarver, 309 F. Supp. 362 (E.D. Ark. I970), aff'd, 442 F.2d 304 (8th Cir. 197 I); Jordan v. Fitzharris, 257 F. Supp. 674 (N.D. Cal. I 966 ).

8. 406 F. Supp. 318 (M.D. Ala. 1976), notice of appeal filed, Civ. No. 74-203-N (M.D. Ala. Apr. 5, 1976). The case was reported in the advance sheets as James $v$. Wallace and commonly is referred to by that name. In the bound volume of the Federal Supplement, however, the case is reported as Pugh $v$. Locke. In the earlier case of James v. Wallace, 382 F. Supp. I 77 (M.D. Ala. 1974), the same court denied the defendant state officials' motion to dismiss on grounds that the complaint, alleging first that the prisoners had been refused an opportunity to rehabilitate themselves, second that they arbitrarily and capriciously had been assigned to units that had no treatment facilities for mental or physical disabilities, and finally that unreasonable restrictions had been placed on their visitation rights, stated a claim upon which relief could be granted. For a discussion of Pugh, see text accompanying notes I I-27 infra.

9. "Excessive bail shall not be required, nor excessive fines imposed, nor cruel and unusual punishments inflicted." U.S. CONST. amend. VIII.

10. "There are today about 400 institutions for adult felons in this country, ranging from some of the oldest and largest prisons in the world to forestry camps for 30 or 40 trusted inmates. 
important legal issues for aggrieved inmates, prison officials and public policymakers. Moreover, in light of the questions of federalism raised by a United States district court's revamping of an entire state prison system, the decision has even broader implications for the federal adjudication of civil rights generally. This Article examines the doctrinal and remedial alternatives suggested by the prison cases, and particularly Pughv. Locke, in light of recent Supreme Court restrictions on federal court intervention in state administrative affairs. After a brief discussion of Pugh and of the federalism issues surrounding that case, the Article turns to the body of law interpreting the eighth amendment in the prison context and then to the specific remedies ordered in Pugh in order to implement that law. Finally, the Article concludes with an examination of the propriety of federal judicial supervision of state prison systems, both in terms of federalism concerns and in light of the more traditional debate over the appropriate role of the judiciary in a democratic society.

\section{Pugh v. Locke-A SYNOPSIS}

An understanding of the innovations in the constitutional theory and the intrusiveness of the remedial program developed in $P u g b$ requires a review of the case and its holding. The plaintiffs in $P u g h$, present and future inmates of Alabama state penal institutions, ${ }^{11}$ sued, in their individual and official capacities, the Governor of Alabama, the Commissioner, Deputy Commissioner and members of the Alabama Board of Corrections, and the wardens of two state correctional facilities, ${ }^{12}$ seeking declaratory and injunctive relief for deprivation of rights under the eighth and I4th amendments. ${ }^{13}$ The court's memorandum opinion consisted

Some are grossly understaffed and underequipped-conspicuous products of public indifference. Overcrowding and idleness are the salient features of some, brutality and corruption of a few others. Far too few are well organized and adequately funded. Juvenile institutions tend to be better, but also vary greatly. The local jails and workhouses that handle most misdemeanants are generally the most inadequate in every way." PRESIDENT's COMMISSION ON LAw ENFORCEMENT AND ADMinistration OF JUSTICE, TASK ForCE REPORT: CORReCTIONS 4 (1967).

In fact, the term "correctional" may be a misnomer. For discussion of this issue, see, e.g., Robbins, Learning by Redoing (Book Review), 77 ColuM. L. REv. I53 (1977); Robbins, Brotbers of Gulag (Book Review), 62 VA. L. REv. 462, 464-65, 468 \& n.36 (1976).

I I. 406 F. Supp. at $32 \mathrm{I}$. The suit was brought as a class action under FED. R. CIv. P. 23(a) and $23(b)(2)$.

12. 406 F. Supp. at 321 .

13. The action was brought under 42 U.S.C. $\$$ r983 (1970): "Every person who, under color of any statute, ordinance, regulation, custom, or usage, of any State or Territory, subjects, or causes to be subjected, any citizen of the United States or other person within the jurisdiction thereof to the deprivation of any rights, privileges, or immunities secured by the Constitution and laws, shall be liable to the party injured in an action at law, suit in equity, or other proper proceeding for redress."

The Supreme Court applied the eighth amendment's ban against cruel and unusual punishment to the states through the I4th amendment in Robinson v. California, 370 U.S. 660 (1962). 
primarily of a litany of undisputed facts concerning the conditions in the state's four principal correctional facilities. ${ }^{14}$ Foremost among these facts was severe overcrowding, which the court found to be "primarily responsible for . . . all the other ills of Alabama's penal system." 15 For example, the lack of adequate facilities mandated the total abnegation of a prisoner classification system, ${ }^{16}$ so that the ro percent of the prison population known to be psychotic ${ }^{17}$ as well as many others known to be violently disposed were dispersed throughout the several prisons. ${ }^{18}$ The court also found that the physical plants, electrical wiring, heating, plumbing, and ventilation were in disrepair and that the decrepit facilities promoted the "gross infestation" of vermin. ${ }^{19}$ Food service equipment and storage and preparation techniques were unsanitary, and personal hygiene among inmates presented "an insurmountable problem."20 Further, overworked prison personnel contributed considerably to "the rampant violence and jungle atmosphere." 21 Finally, the court characterized the vocational, educational, work, and recreational programs available to Alabama state prisoners as "totally inadequate to provide reasonable opportunities for rehabilitation - or even to prevent physical and mental deterioration-of most of the inmate population." 22 On the basis of these findings, the court concluded that "[t]he living conditions in Alabama prisons constitute[d] cruel and unusual punishment."23

In response to the ubiquitous ills that plagued the Alabama prisons, the court devised an equally all-encompassing remedy. First, it promulgated a detailed set of "Minimum Constitutional Standards for Inmates of

14. 406 F. Supp. at 322-28. The cases were submitted on evidence offered at trial, as well as on depositions, briefs and more than 1,000 stipulated facts. See id. at 322 .

15. Id. at 323. The court noted that at the time of trial some 3,550 inmates were incarcerated in the four major Alabama penal institutions designed to house a maximum of 2,307 inmates. Id. at 322. Accord, McCray v. Sullivan, 399 F. Supp. 27 I (S.D. Ala. 1975); see notes $103-05$ \& $166-70$ infra and accompanying texts.

16. $406 \mathrm{~F}$. Supp. at $324-25$.

17. Id. at 324 .

18. Id. See also notes 106-09 infra and accompanying text.

19. 406 F. Supp. at 323. See also H. Charriere, Papilion (1970).

20. $406 \mathrm{~F}$. Supp. at 323. A United States public health officer toured the four main Alabama facilities and found them "wholly unfit for human habitation according to virtually every criterion used for evaluation by public health inspectors." Id. at 323-24. This officer testified that, if such facilities were under his jurisdiction, he would recommend that they be closed and condemned "as an imminent danger to the health of the individuals exposed to them." Id. at 324. See notes $126 \& 169$ infra.

21. 406 F. Supp. at 325 .

22. Id. at 326 .

23. Id. at 329. The proffered defense that the conditions of confinement were directly related to inadequate funding by the state legislature was summarily rejected. Id. at 330-3I. See note 93 infra. 
Alabama Penal System" 24 and ordered the defendants to report to the court in 6 months concerning "their programs in the implementation of each and every standard." 25 The court also ordered the state to form a Human Rights Committee for the Alabama Prison System to monitor the implementation of the standards. ${ }^{26}$ Finally, the court placed the defendant state officials "on notice that failure to comply with the minimum standards . . . will necessitate the closing of those several prison facilities herein found to be unfit for human confinement."27 Taken together, these requirements constituted the most ambitious federal court intervention in the field of corrections.

\section{Counter TRends New ANd Old: PROBLEMS OF FEDERALISM AND EXPERTISE}

Although federal courts previously had threatened to close penal facilities and had required prison officials to report on their continuing progress, ${ }^{28}$ none before $P$ ugh had declared, for example, that the Constitution guarantees each inmate 60 square feet of living space or a sink with hot and cold running water in his cell. ${ }^{29}$ And few courts had divested state officials so completely of primary authority for running a state institution.

Not so long ago, however, the Pugh court's remedy might have been viewed as a logical step toward the protection of federally guaranteed rights against recalcitrant state officials. The school desegregation cases had set ample precedent for federal intervention in activities traditionally left within the province of the states, ${ }^{30}$ and the Supreme Court not only had permitted but also had mandated imaginative expansion of federal equity powers to deal with deprivations of constitutional rights. ${ }^{31}$

Recently, however, the Supreme Court has reversed this trend and shown a new concern with principles of federalism in dealing with state officials. This new concern began in I97 I with Younger v. Harris, ${ }^{32}$ which

24. $406 \mathrm{~F}$. Supp. at 332. See text accompanying notes $145-70$ infra for a discussion of the promulgated standards.

25. 406 F. Supp. at 332 .

26. Id. at $33 \mathrm{I}$.

27. Id.

28. See, e.g., Brenneman v. Madigan, 343 F. Supp. 128, 133, 142-43 (N.D. Cal. 1972).

29. 406 F. Supp. at 332. See notes I66-70 infra and accompanying text.

30. See, e.g., Green v. County School Bd., 39 I U.S. 430 (1968); Brown v. Board of Educ., 349 U.S. 294 (1955) (Brown II).

31. See, e.g., Swann v. Charlotte-Mecklenburg Bd. of Educ., 402 U.S. I, 28 (I97 I) ("[T] he remedy for such segregation may be administratively awkward, inconvenient and even bizarre in some situations and may impose burdens on some; but all awkwardness and inconvenience cannor be avoided in the interim period when remedial adjustments are being made to eliminate the dual school system."); note 49 infra.

32. 401 U.S. 37 (r97I). 
prohibited federal courts from enjoining pending state criminal prosecutions under section 1983 of the Civil Rights Act. ${ }^{33}$ Since Younger, the Court has extended its prohibition of federal court interference in state courts to cases involving state civil proceedings that are similar to criminal prosecutions, such as state nuisance actions against pornographic theaters. ${ }^{34}$ Most recently, in Rizzov. Goode, ${ }^{35}$ the Court held that a federal district court exceeded its authority in requiring that the Philadelphia Police Department draft and submit guidelines for dealing with civilian complaints of constitutional violations. In so doing, the Court noted that "the principles of federalism which play such an important part in governing the relationship between federal courts and state governments" 36 govern requests for injunctions not only against state judicial proceedings but against "those in charge of . . . an agency of state or local governments" 37 as well.

Although Rizzo probably rests most firmly on the Court's alternative holding that no cause of action had been shown under section $1983,{ }^{38}$ its broad federalism dicta portend a Court bent on limiting federal intervention against state officials. Moreover, unlike the Pugb court's order, containing detailed instructions and requiring the establishment of a committee with broad powers of oversight, ${ }^{39}$ the remedy overturned in Rizzo merely ordered the police department to draft and implement guidelines. ${ }^{40}$

Rizzo's concern for principles of federalism may have additional vitality in the prison context in light of the hands-off approach ${ }^{41}$ that traditionally has precluded federal courts from entertaining state prisoners' allegations of unconstitutional treatment. ${ }^{42}$ The concept was predicated upon the belief that the inmate was a "slave of the State" 43 who had no rights for the

33. 42 U.S.C. $\$ 1983$ ( 1970 ), quoted in note 13 supra.

34. Huffman v. Pursue, Ltd., 420 U.S. 592 (1975). See Bartels, Avoiding a Comity of Errors: A" Model for Adjudicating Federal Civil Rights Suits that "Interfere" with State Civil Procedings, 29 STAN. L. REV. 27 (I976).

35. 432 U.S. 362 (1976).

36. $I d$. at 380 .

37. Id. See Note, Rizzo v. Goode: Federal Remedies for Police Misconduct, 62 VA. L. REv. I $259(1976)$.

38. 432 U.S. at 377. See The Supreme Court, 1975 Term, 90 HaRv. L. Rev. 238 (1976).

39. See notes $147-52$ infra and accompanying text.

40. Council of Orgs. on Phila. Police Accountability and Responsibility v. Rizzo, 357 F. Supp. 1 289, 132 I (E.D. Pa. 1973), aff'd sub nom. Goode v. Rizzo, 506 F.2d 542 (3d Cir. 1974), rev'd, 423 U.S. 362 (1976).

4I. See Comment, Beyond the Ken of the Courts: A Critique of Judicial Refusal to Reriew the Complaints of Convicts, 72 YALE L.J. 506 (1963). See also Hirshkop \& Millemann, The Unconstitutionality of Prison Life, 55 VA. L. Rev. 795 (1969); Note, Constitutional Rights of Prisoners: The Deteloping Lau', I IO U. PA. L. REV. 985 (1962).

42. See, e.g., Bethea v. Crouse, 417 F.2d 504, 505-06 (Ioth Cir. 1969) (historical discussion); Banning v. Looney, 213 F.2d 77 I (I och Cir.), cert. denied, 348 U.S. 859 (I954); Stroud v. Swope, 187 F.2d 850 (9th Cir.), cert. denied, 342 U.S. 829 (1951).

43. Ruffin v. Commonwealth, 62 Va. (2I Gratt.) 790 , 796 (I87I); see Ex parte Pickens, 
sovereign to violate. The doctrine retains modern vitality in part because of the judiciary's natural reluctance to intervene in affairs of internal prison administration that appear to involve a high degree of expertise and discretion. ${ }^{44}$ Moreover, cognizant of the principles of separation of powers and federalism, the federal courts even today view corrections as a matter primarily of executive - and in cases involving state prisons, of stateconcern. ${ }^{45}$ The passage in the post-bellum period of the Federal Civil Rights Acts ${ }^{46}$ provided a potential mandate for judicial intervention, thus weakening the underpinnings of the hands-off doctrine. But a century later federal courts still routinely refuse to encroach upon the supervision of daily prison life. ${ }^{47}$ Although, in the face of a clear constitutional violation, modern federal courts often have abandoned this deference ${ }^{48}$ and invoked a broad range of equitable remedies, ${ }^{49}$ including injunctions, ${ }^{50}$ monetary

IOI F. Supp. 285 (D. Alas. I95 I); if. U.S. CONST. amend. XIII, $\mathbb{S}$ I (exempting convicts from the proscription against slavery and involuntary servitude).

44. See note 69 infra; notes 108 \& $187-91$ infra and accompanying texts.

45. "We do not doubt the magnitude of the task ahead before our correctional systems become acceptable and effective from a correctional, social and humane viewpoint, but the proper tools for the job do not lie with a remote federal court. The sensitivity to local nuance, opportunity for daily perseverance, and the human and monetary resources required lie rather with legislators, executives, and citizens in their communities." Sostre v. McGinnis, 442 F.2d r78, 205 (2d Cir. 197 I) (en banc), cert. denied, 404 U.S. I049, 405 U.S. 978 (I972). Cf. McRedmond v. Wilson, 533 F.2d 757, 766 (2d Cir. 1976) (Van Graafeiland, J., dissenting) ("[A] federal judge rearranging a State's penal . . . system is like a man feeding candy to his grandchild. He derives a great deal of personal satisfaction from it and has no responsibility for the results."). Supervision of the federal prison system is vested in the Attorney General of the United States. See 18 U.S.C. $\$ 4042$ (1970). See generally notes 205-07 infra and accompanying text.

46. 42 U.S.C. $\$ \$ 1981-1995$ (1970).

47. See, e.g., Procunier v. Martinez, 416 U.S. 396, 404-05 (1974); Novak v. Beto, 453 F.2d 66r, 670-71 (5th Cir. 197I), cert. denied, 409 U.S. 968 (1972); Queen v. South Carolina Dep't of Corrections, 307 F. Supp. 84I (D.S.C. I970).

48. "[C]onstitutional deprivations of the magnitude presented here simply cannot be countenanced, and this Court is under a duty to, and will, intervene to protect incarcerated citizens from such wholesale infringements of their constitutional rights." Pugh v. Locke, $406 \mathrm{~F}$. Supp. 318, 328 (M.D. Ala. I976); accord, Cruz v. Beto, 405 U.S. 319, 32 I (I972) (per curiam); Miller v. Carson, 401 F. Supp. 835, 865 (M.D. Fla. 1975); $f$. McRedmond v. Wilson, 533 F.2d 757, 760 (2d Cir. 1976), quoting Stapleton v. Mitchell, 6o F. Supp. 51, 55 (D. Kan. 1945) ("W]e yet like to believe that wherever the Federal courts sit, human rights under the Federal Constitution are always a proper subject for adjudication . . . ."). See notes 192-95 infra and accompanying text.

49. Cf. Swann v. Charlotte-Mecklenberg Bd. of Educ., 402 U.S. I, Is (I97I) (school desegregation) ("[O]nce a right and a violation have been shown, the scope of a district court's equitable powers to remedy past wrongs is broad, for breadth and flexibility are inherent in equitable remedies."). But see Rizzo v. Goode, 423 U.S. 362, 377 (1976). See generally Comment, Equitable Remedies Available to a Federal Court After Declaring an Entire Prison System Violates the Eightb Amendment, I CAP. U.L. REV. IOI (1972). Reference to a school desegregation case is not accidental, for the experience of the federal judiciary is analogous. See generally Comment, Cruel But Not So Unusual Punishment: The Role of the Federal Judiciary in State Prison Reform, 7 CUM. L. REv. 31, 37-38, 57-58 (1976).

50. See, e.g., Johnson v. Avery, 393 U.S. 483 (1969) (regulation prohibiting mutual inmate legal assistance enjoined); Jackson v. Bishop, 404 F.2d 57 I (8th Cir. 1968) (use of strap 
damages, ${ }^{51}$ contempt citations, ${ }^{52}$ and even release from confinement, ${ }^{53}$ the hands-off doctrine remains atmospherically important to the initial determination of the need for as well as the degree of intervention.

In sum, the holding in Pugh can withstand the doubts cast upon it by Rizzo and reinforced in the prison context by the traditional hands-off approach only upon a showing that it is intrinsically different from Rizzo either because of the strength of the precedential value of modern prison cases, the newly developing strictures of the eighth amendment or the fact that no other remedy is available to the court.

\section{CONDITIONS OF CONFINEMENT: \\ The Determination of Cruel and Unusual Punishment}

In order to understand the lengths traveled by the $P$ ugh court in fashioning the remedy, it is first necessary to advert to the breadth of the constitutional harm found by the court. Understanding the harm in turn requires some knowledge of the doctrinal train of events culminating in the finding that the totality of the conditions of confinement facing prisoners could constitute cruel and unusual punishment.

\section{A. Three Doctrinal Approaches to Cruel and Unusual Punishment}

Although the origin of the phrase "cruel and unusual punishments" is well-established, ${ }^{54}$ its original meaning has been obfuscated. ${ }^{55}$ The common law view of the term, however, clearly did not prohibit the imposition of brutal punishments for the commission of heinous crimes. ${ }^{56}$

to inflict corporal punishment enjoined); Castor v. Mitchell, 355 F. Supp. I23 (W.D.N.C. 1973) (practice of awakening prisoner every 30 minutes enjoined).

5I. See, e.g., Sostre v. McGinnis, 442 F.2d 178 (2d Cir. I97I) (en banc), cert. denied, 404 U.S. I049, 405 U.S. 978 (1972) (dicta) (warden's improper conduct of segregating prisoner was proper subject of compensatory damages); Landman v. Royster, 354 F. Supp. 1302 (E.D. Va. 1973), enforcing 333 F. Supp. 62 (E.D. Va. 1971) (inmates deprived of constitutional rights due to improper solitary confinement entitled to reasonable sums for cost of future medical treatment, loss of prison wages and pain and suffering).

52. See, e.g., Landman v. Royster, 354 F. Supp. I292 (E.D. Va. 1973), inforcing 333 F. Supp. 62I (E.D. Va. I97I).

53. Cf. Rhem v. Malcolm, 377 F. Supp. 955 (S.D.N.Y.), enforcing 37 I F. Supp. 594 (S.D.N.Y.), aff'd and remanded, 507 F.2d 333 (2d Cir. 1974), on remand, 389 F. Supp. 964 (S.D.N.Y.), aff'd, 527 F.2d 104I (2d Cir. 1975) (ordering jail to be closed if conditions not remedied within 30 days). See generally Note, Courts, Corrections and the Eighth Amendment: Encouraging Prison Reform by Releasing Inmates, 44 S. CAL. L. REV. Io6o (197I).

54. BRITish Declaration of Rights of I688; see I W. \& M. 2, c. 2 (i688).

55. See generally Granucci, "Nor Cruel and Unusual Punishments Inflicted": The Original Meaning, 57 CaLIF. L. REv. 839 (1969).

56. See 4 W. Blackstone, Commentaries on the Laws of ENGLand $1510-1$ I (T. Cooley \& J. Andrews $4^{\text {th }}$ ed. 1899): "Of these [permissible punishments], some are capital, which extend to the life of the offender, and consist generally in being hanged by the neck till dead; though in very atrocious crimes other circumstances of terror, pain or disgrace, are superad- 
The earliest American courts to consider the matter equated cruelty with "something inhuman and barbarous, something more than the mere extinguishment of life."57 The more modern American attitude toward cruel and unusual punishment emanates from Weems $v$. United States. ${ }^{58}$ This case involved an accessory in the falsification of a public document, who was punished with a 12-to-20 year sentence at hard labor with ankle and wrist chains and the perpetual loss of civil rights. The Supreme Court found the punishment excessive, declaring that the humanitarian leitmotiv of the eighth amendment was not to be hampered by the common law's traditional allowance of brutal penalties. ${ }^{59} \mathrm{It}$ is also now settled that the term "punishments" is construed to include not only statutorily imposed sentences, but ad hoc sanctions meted out by prison officials as well. ${ }^{60}$ Chief Justice Burger has noted, in fact, that "[j]udicial findings of impermissible cruelty have been limited, for the most part, to offensive punishments devised without specific authority by prison officials, not by legislatures." 61 Further, as exemplified in Pugb v. Locke, "punishments" is interpreted to embrace conditions of incarceration that affect an entire prison population simply as a consequence of confinement. ${ }^{62}$

In recent years, courts predominantly have employed three somewhat overlapping approaches to determine the presence of cruel and unusual punishment: whether the punishment "shocks the conscience," whether it is disproportionate to the offense committed and whether it is in excess of a legitimate penal aim. ${ }^{63}$ Each approach, however, suffers from severe

ded; as, in treasons of all kinds, being drawn or dragged to the place of execution; in high treason affecting the king's person or government, emboweling alive, beheading, and quartering; and in murder, a public dissection. And, in case of any treason committed by a female, the judgment is to be burned alive. But the humanity of the English nation has authorized, by a tacit consent, an almost general mitigation of such parts of these judgments as savour of torture or cruelty . . . . Some punishments consist in exile or banishment, others in loss of liberty, by perpetual or temporary imprisonment. Some extend to confiscation, others induce a disability. Some, though rarely, accasion a mutilation or dismembering, by cutting off the hand or ears, others fix a last stigma on the offender, by slitting the nostrils, or branding in the hand or cheek."

57. In re Kemmler, 136 U.S. 436, 447 (I890). "[I]f the punishment . . . were manifestly cruel and unusual, as burning at the stake, crucifixion, breaking on the wheel, or the like, it would be [unconstitutional] . . . Id. at 446 .

58. 217 U.S. 349 (1910).

59. Id. at 378 (The amendment "may be . . progressive, and is not fastened to the obsolete but may acquire meaning as public opinion becomes enlightened by a humane justice.").

6o. See, e.g., Jackson v. Bishop, 404 F.2d 571 (8th Cir. 1968); Landman v. Royster, 333 F. Supp. 62 I (E.D. Va. 197 I), enforced, 354 F. Supp. I302 (E.D. Va. 1973). But see Negrich v. Hohn, 246 F. Supp. 173, 176 (W.D. Pa. 1965); Hill v. State, I19 Ga. App. 612, 614, 168 S.E.2d 327,330 (1969).

6I. Furman v. Georgia, 408 U.S. 238, 384 (1972) (Burger, C.J., dissenting).

62. See text accompanying notes is-23 supra.

63. Recent Supreme Court discussions of the eighth amendment, primarily in the context of capital punishment, include Gregg v. Georgia, 96 S. Ct. 2909 (1976) (death penalty statute utilizing guided discretion of sentencing authority is constitutional); Furman v. Georgia, 408 
doctrinal and historical limitations that make it virtually irrelevant in the context of an eighth amendment examination of the totality of prison conditions. A brief description and analysis of the three approaches will indicate why the courts that have based massive remedial measures on the unconstitutionality of particularly abject prison conditions have abandoned these approaches in search of new ones.

\section{Punishment that shocks the conscience.}

The "shock the conscience" test has been the standard most extensively applied to determine the constitutionality of particular punishments. Pursuant to this approach, the court bases its holding of unconstitutionality on a "cry of horror" 64 at punishment that is "so foul, so inhuman and so violative of basic concepts of decency" that it shocks the conscience of the court. ${ }^{65}$ This standard, which has been criticized as being overly subjective for purposes of a constitutional test, ${ }^{66}$ is indicative of an evolutionary theory of punishment, without which the eighth amendment would provide little modern protection. ${ }^{67}$

Despite its flexibility, however, the "shock the conscience" test is effective only when the features of confinement are so readily discernible as to evoke predictable human affections. The value of the test diminishes critically when such subtly effective penalties as prison conditions that may

U.S. 238 (1972) (certain death penalty statutes result in the arbitrary infliction of capital punishment and are unconstitutional); MCGautha v. California, 402 U.S. 183 (197I) (statute leaving death penalty to unguided discretion of jury is constitutional; partially overruled in Gregg v. Georgia, 96 S. Cr. 2909 , 2936 n.47 (1976)); Robinson v. California, 370 U.S. 660 (1962) (applying eighth amendment to invalidate state law criminalizing narcotics addiction); Trop v. Dulles, 356 U.S. 86 ( 1958 ) (plurality opinion) (the stigma and other harm caused by denationalization can be cruel and unusual punishment).

64. Robinson v. California, 370 U.S. 660, 676 (1962) (Douglas, J., concurring).

65. Wright v. McMann, 387 F.2d 519, 526 (2d Cir. 1967), an remand, 321 F. Supp. I 27 (N.D.N.Y. 1970), aff'd in part and rev'd in part, 460 F.2d I26 (2d Cir. 1972), cert. dentid, 409 U.S. 885 (1972); accord, e.g., Burns v. Swenson, 430 F.2d 771, 778 (8th Cir. 1970), cort. denid, 404 U.S. 1062 (1972) ("base, inhumane, and barbaric . . . so as to shock and offend a court's sensibilities"); Holt v. Sarver, 309 F. Supp. 362, 380 (E.D. Ark. 1970), aff'd, $44^{2}$ F.2d 304 (8th Cir. I97I) ("shocking or disgusting to people of reasonable sensitivity"); of. Rochin v. California, 342 U.S. 165,172 (1952) (conditions, to violate dictates of due process, should offend more than some mere "fastidious squeamishness or private sentimentalism").

66. The standard allows the courts to "roam at will in the limitless area of their beliefs." FPC v. Natural Gas Pipeline Co., 315 U.S. 575, 600-01 n.4 (1942) (Black, J., concurring); accord, Rochin v. California, 342 U.S. 165, 174-77 (1952) (Black, J., concurring); Adamson v. California, 322 U.S. 46, 68-92 (1947) (Black, J., dissenting); Goldberg \& Dershowitz, Declaring the Deatb Penalty Unonstitutional, 83 HaRv. L. REv. 1773, 1778-79 (1970).

67. Thus, the punishments chronicled by Blackstone as permissible under common law perceptions of cruel and unusual punishment, see note 56 supra, would shock the consciences of most judges today. Ste generally Robbins, Learning by Redoing, supra note ro. 
affect their victims over long periods of time are involved. ${ }^{68}$ The other major difficulty with using this subjective test in the prison context is that it provides no guidelines by which prison authorities might anticipate litigation and voluntarily conform to federal constitutional standards. Mere moral outrage by a federal judge does little to provide prison officials with any basis for the establishment of prison policies and standards of confinement. ${ }^{69}$

\section{Punishment disproportionate to the offense committed.}

A-şecond, less prevalent, approach used to ascertain the presence of cruel and unusual punishment compares the sanction imposed with the act perpetrated to determine whether the punishment is excessive. ${ }^{70}$ Because

68. For example, psychological extirpation, which prisons are quite capable of causing, may involve greater anguish to the victim than many forms of corporal punishment. The Supreme Court broached this subject in Trop v. Dulles, 356 U.S. 86 (1958), holding that the use of denationalization as a punishment was barred by the eighth amendment. The Court stated that "[t]here may be involved no physical mistreatment, no primitive torture. There is instead the total destruction of the individual's status in organized society. It is a form of punishment more primitive than torture, for it destroys for the individual the political existence that was centuries in the development." Id. at $10 \mathrm{I}$ (plurality opinion per Warren, C.J.). Although the Chief Justice was speaking only for a plurality (with Justices Black, Douglas and Whittaker), a majority of the Court referred approvingly to these words in Furman v. Georgia, 408 U.S. 238 (1972). See id. at 2,42 (Douglas, J., concurring); id. at 269-70 (Brennan, J., concurring); id. at $306 \mathrm{n}$. I (Stewart, J., concurring); id. at 327 (Marshall, J., concurring); id. at 409 (Blackmun, J., dissenting); accord, Sostre v. McGinnis, 442 F.2d I78, 208 (2d Cir. i97I) (en banc), cert. denied, 404 U.S. 1049,405 U.S. 978 (1972) ("true inhumanity seeks to destroy the psyche rather than merely the body") (Feinberg, J., dissenting and concurring). See also I A. SOLZHENITSYN, THE GULAG ARCHIPELAGO 1918-1956: AN EXPERIMENT IN LITERARY INVESTIGATION (1973); 2 id. (1975). For a brief comparison of the Soviet and American prison systems emphasizing their relative uses of psychological pressure, see Robbins, Brothers of Gulag, note io supra.

69. Perhaps the reason for this discrepancy is that we do not, and, perhaps, cannot know the least common denominators for security or discipline or what factors can be said with certitude to promote rehabilitation. Cf., e.g., Roberts v. Pepersack, 256 F. Supp. 4I5, 430-31 (D. Md. 1966), ctrt. denied, 389 U.S. 877 ( 1967 ) ( 27 hours in isolation during which prisoner allegedly was forced to go naked and to lie on a cold concrete floor without a mattress or blankets in temperarure of abour 40 degrees and an additional I 6 days of semisegregation held not to be cruel and unusual punishment, because the inmate's violations of rules had threatened prison order). From a different, societal, perspective, the "shock the conscience" test also suffers from the possibility that what a lay person may consider brutal is essential for the maintenance of prison security, discipline or the promotion of rehabilitation. As one court has noted: "Even a lifetime of study in prison administration and several advanced degrees in the field would not qualify us as a fidval court to command state officials to shun a policy that they have decided is suitable because to us the choice may seem unsound or personally repugnant." Sostre v. McGinnis, 442 F.2d 178, I91 (2d Cir. I97I) (en banc), cert. denied, 404 U.S. 1049, 405 U.S. 978 (1972). See generally Kaufman, Prison: The Judge's Dilemma, 4I FORDHAM L. REv. 495, 508 (1973); notes 4I-45 supra and accompanying text.

70. Dissenting in O'Neil v. Vermont, I44 U.S. 323, 337 (1892), Justice Field indicated that excessiveness in length or severity of punishment in relation to the offense charged was of primary significance in adjudicating violations of the eighth amendment. Id. at 339-40 (Field, J., 
this test was developed in cases involving the trial judge's or prison official's discretionary power in imposing specific sanctions, generally increasing those already meted out at sentencing, ${ }^{71}$ it is particularly inappropriate in evaluating ongoing conditions of confinement for the general prison population. Challenges to a cumulation of prison conditions that daily affect the inmate community and that do not include the imposition of extra punishments following particular transgressions of prison regulations cannot profitably draw on this essentially transactional theory.

\section{Punishment in excess of a legitimate penal aim.}

Under the third approach to determining the existence of cruel and unusual punishment, a composite of the "shock the conscience" and "excessiveness" tests, "a punishment may be cruel and unusual when, although applied in pursuit of a legitimate penal aim, it goes beyond what is necessary to achieve that aim; that is, when a punishment is unnecessarily cruel in view of the purpose for which it is used."72 This standard still considers the degree of brutality, but, having found punishment or confinement conditions to be shocking, it compares the justification for the punishment imposed. Government personnel have the burden of defending prison policies with reference to legitimate penal objectives. ${ }^{73}$

dissenting); $f$. Pervear v. Commonwealth, 72 U.S. (5 Wall.) 475, 480 (I866) ("[W]e perceive nothing excessive, or cruel, or unusual in this [punishment].") One writer has viewed an "excessive or unnecessary pain" test as "the minimum content of the eighth amendment." Note, Revival of the Eighth Amendment: Development of Cmel-Punishment Doctrine by the Supreme Court, 16 STAN. L. Rev. 996, 1003-I5 (1964). But see Gregg v. Georgia, 96 S. Ct. 2909, 2925 (1976) (plurality opinion).

71 . Most cases in which the courts have employed this test actually have involved imposition of the sanction of solitary confinement, a process not unlike the original sentencing in the sense that a further punishment is exacted for a furcher violation. See, e.g. , Landman v. Royster, 333 F. Supp. 62I (E.D. Va. I97I), enforced, 354 F. Supp. I302 (E.D. Va. 1973); Wright v. McMann, 32 I F. Supp. 127 (N.D.N.Y. 1970), aff'd in part and rev'd in part, 460 F.2d 126 (2d Cir. 1972), cert. denied, 409 U.S. 885 (1972); Carothers v. Follette, 314 F. Supp. IOI4 (S.D.N.Y. 1970). See generally Note, Decency and Fairness: An Emerging Judicial Role in Prison Reform, 57 VA. L. REv. 841,852-55 (1971).

On the application of the due process clause to prison disciplinary proceedings, see Baxter v. Palmigiano, 96 S. Ct. I55 I (1976); Wolff v. McDonnell, 418 U.S. 539 (1974).

72. Jordan v. Fitzharris, 257 F. Supp. 674, 679 (N.D. Cal. I966); accord, Weems v. United States, 217 U.S. 349, 37 I (1910). See generally Packer, Making the Punishment Fit the Crime, 77 Harv. L. Rev. I07I (1964); Note, The Cruel and Untsual Punishment Clause and the Substantize Criminal Law", 79 HARv. L. Rev. 635 (1966).

73. In Pugh v. Locke, 406 F. Supp. 3 I 8 (M.D. Ala. 1976), for example, the court identified "three legitimate functions of a correctional system: deterrence, both specific and general; rehabilitation; and institutional security." Id. at 328, citing Pell v. Procunier, 417 U.S. $817,822-23$ (1974). The court added that "[w]hen an inmate is restricted in a manner which supports no such valid purpose, that restriction cannot stand." $406 \mathrm{~F}$. Supp. at 328 . It is worthy 
Theoretically, this burden ensures the expert presentation of objective data, so that the court may rule on more than a purely moral or "gut reaction" basis.

As with the other two tests, this balancing, or "punishment in excess of legitimate penal aim" test, involves significant problems in the context of overall prison conditions. First, it primarily addresses disciplinary sanctions, rather than the nondiscretionary toleration of conditions of confinement. Second, in the broad context of the totality of conditions facing a prisoner, the conceptions of penal aims relied upon by this third cruel and unusual punishment formulation become themselves so general ${ }^{74}$ that the expertise and objective data available in the context of more individual punishments will not be available. The test, therefore, becomes even more amorphous and subjective than the ones it replaces, for it then amounts to the balancing of two imponderables: the judge's shocked conscience and the penological justification for imprisonment. Third, although this test might seem burdensome for the prison officials involved, in practice the courts often defer to the officials' statements of need, rather than face the multitude of problems involved in any general attack on prison-wide conditions. ${ }^{75}$ Thus, serious question exists whether this test is consonant with the general theory of cruel and unusual punishment, or whether it constitutes a "gross distortion" of the eighth amendment. ${ }^{76}$

of note that the court overlooked the often-neglected function of punishment per se. See generally A. von Hirsch, Doing Justice: The ChOICE of Punishments 45-55 (1976). After balancing the totality of conditions of confinement against these acknowledged goals of the correctional system, the Pugh court concluded that "[t] he conditions in which Alabama prisoners must live . . bear no reasonable relationship to legitimate institutional goals." 406 F. Supp. at 329.

At its base, the test is a derivative of the I 4 th amendment substantive due process analysis commonly applied in prisoner cases involving first amendment rights. See, e.g., Pell v. Procunier, 417 U.S. $817,822-23$ (1974) (no right to press and other media interviews). In the prison context, see Procunier v. Martinez, 4 I 6 U.S. 396, 4 I I (I974) (right to correspondence without censorship), quoting United States v. O'Brien, 39I U.S. 367, 377 (1968): “[A] government regulation is sufficiently justified if it is within the constitutional power of the Government; if it furthers an important or substantial governmental interest; if the governmental interest is unrelated to the suppression of free expression; and if the incidental restriction on alleged First Amendment freedoms is no greater than is essential to the furtherance of that interest." See stmrally Fox, The First Amendment Rights of Prisoners, 63 J. CRIM. L.C. \& P.S. 162 (1972); Note, Priwm Mail Cenimship and the First Amendment, 81 YALE L.J. 87 (I97 I). The standard includes a "less drastic alternative" corollary under which living conditions are declared constitutional if established penal goals could be attained without requiring a prisoner to live in "exacerbated conditions of filth and discomfort." Hancock v. Avery, 30I F. Supp. 786, 792 (M.D. Tenn. 1969); accurd, Jordan v. Fitzharris, 257 F. Supp. 674 (N.D. Cal. I966).

74. With individual punishments, the question of state justification is a matter subject to expertise and objective data. But in cases involving the totality of conditions of confinement, the state's penological justification necessarily broadens, and the debate rarely will stop short of questioning the very concept of prison itself, a matter clearly beyond the expertise of the courts. Stc Robbins, Learning by Redoing, supra note 10 ; note 69 supra and accompanying text.

75. Ste getterally Kaufman, supra note 69.

76. Furman v. Georgia, 408 U.S. 238, 392 (1972) (Burger, C.J., dissenting). 
Despite the inadequacy of these three approaches to cruel and unusual punishments, the courts have not hesitated to use them. ${ }^{77}$ Just as often, however, especially of late, they have ignored them and used basically inductive reasoning from factual findings ${ }^{78}$ in order to find that certain particularly vile prison conditions violate the Constitution. The courts have been more likely to use the three approaches in cases of individual deprivations, and they have found it easiest to make the inductive leap from the facts to a finding of unconstitutionality in cases in which the offending conditions are systemic and widespread. The pervasiveness of these conditions in turn often has inflated the scope of the remedy ordered by the court. To understand those remedies it is crucial, therefore, to analyze the prison conditions that have prompted these judicial findings of cruel and unusual punishment.

\section{B. Conditions of Confinement as Per Se Violations of the Eighth Amendment: The Search for a More Practical Doctrine}

\section{The "totality of conditions" approach: a first step.}

Judicial holdings that conditions of confinement are per se violative of the eighth amendment ${ }^{79}$ are relatively new in the development of the cruel and unusual punishment clause. Not only does this recent doctrinal development threaten to replace the three traditional approaches under the eighth amendment, at least in prison conditions litigation; it also warrants more adventuresome remedies. The decision in Holt $v$. Sarver ${ }^{80}$ initiated the new trend by holding that a cumulation of conditions might constitute cruel and unusual punishment.

The multitude of substandard prison conditions chronicled in Holt stands as a sordid shrine in American correctional history. ${ }^{81}$ No other case

77. See, e.g., Estelle v. Gamble, 97 S. Ct. 285 (1976) (improper medical treatment); Rozecki v. Gaughan, 459 F.2d 6 (Ist Cir. 1972) (improper heating system); Kish v. County of Milwaukee, 44I F.2d $90 \mathrm{I}$ (7th Cir. I97I) (failure to protect prisoners from assault); Landman v. Royster, 333 F. Supp. 62 I (E.D. Va. I97I), enforced, 354 F. Supp. I 302 (E.D. Va. I 973) (bread and water diet); Sinclair v. Henderson, 33I F. Supp. II23 (E.D. La. 1971) (lack of exercise); Sawyer v. Sigler, 320 F. Supp. 690 (D. Neb. 1970), aff'd, 445 F.2d 818 (8th Cir. 1971) (improper medical treatment).

78. "[I]t is the very confinement itself which impermissibly contravenes the Eighth and Fourteenth Amendment rights of the plaintiff classes." Pugh v. Locke, $406 \mathrm{~F}$. Supp. 318, 329 (M.D. Ala. I976); see Gates v. Collier, 50I F.2d I29I, I300-or (5th Cir. 1974); Novak v. Beto, 453 F.2d 66I, 675 (5th Cir. 197 $\mathrm{I}$ ) (Tuttle, J., concurring in part and dissenting in part), cert. denied, 409 U.S. 968 (1972); Holt v. Sarver, 309 F. Supp. 362, 372-73 (E.D. Ark. 1970), aff'd, 442 F.2d 304 (8th Cir. 197I); Hancock v. Avery, 30I F. Supp. 786, 79 I (M.D. Tenn. 1969); Commonwealth ex rel. Bryant v. Hendrick, 444 Pa. 83, 95-98, 280 A.2d 1 10, 1 I 6-I7 (197 I).

79. See cases cited in note 78 supra.

80. 309 F. Supp. 362 (E.D. Ark. 1970), aff'd, 442 F.2d 304 (8th Cir. 1971).

81. Numerous legal periodicals have noted the significance of Holt. E.g., 20 Drake L. Rev. I88 (I97I); 84 HaRv. L. Rev. 456 (1970); 36 Mo. L. Rev. 576 (1971); 3 Seton Hall L. Rev. I59 (I97I); 48 Tex. L. Rev. I 198 (I970); 45 TUL. L. Rev. 403 (I971). 
to date has portrayed such a collection of depraved conditions as those at the Cummins and Tucker Prison Farm in Arkansas. Although the primary significance of Holt is in the court's decision to consider prison conditions in their totality, ${ }^{82}$ the extreme factual situation qualified its value for subsequent litigation by removing the necessity of discussing minimum constitutional standards. Moreover, the court's principal reliance upon two particularly grievous conditions ${ }^{83}$ limited its precedential value in cases involving relatively more typical prison conditions. Nonetheless, in cursorily mentioning inadequate medical and dental facilities, ${ }^{84}$ unsanitary kitchen conditions, ${ }^{85}$ churlish policies regarding personal hygiene, ${ }^{86}$ and an absence of rehabilitation programs ${ }^{87}$ as conditions that "do not rise to constitutional dignity but which aggravate the more serious prison defects and deficiencies," the court tentatively brought the more prosaic conditions of confinement within the ken of eighth amendment review. ${ }^{88}$

Although tracking its language, subsequent courts did not immediately adopt the Holt court's approach of examining the totality of routine prison-wide conditions. Instead, they typically cited Holt in scrutinizing the subset of those conditions that were specifically designed for prison discipline ${ }^{89}$ and in cases involving unconvicted pretrial detainees in local jails. ${ }^{90}$ Pugb v. Locke, therefore, was the first case to emulate

82. "The distinguishing aspects of Arkansas penitentiary life must be considered together. One cannot consider separately a trusty system, a system in which men are confined together in large numbers in open barracks, bad conditions in the isolation cells, or an absence of a meaningful program of rehabilitation. All of those things exist in combination; each affects the other; and taken together they have a cumulative impact on the inmates regardless of their status." $309 \mathrm{~F}$. Supp. at 373 .

83. Highlighting this situation were a brutal "trusty" system and open-barrack sleeping arrangements. The Arkansas prisons primarily depended on armed inmate trusties for prison discipline: "The reasons for penological disapproval of the use of trusty guards are that it creates an unhealthy prison climate and atmosphere; it breeds fear and hatred between the guards, on the one hand, and those guarded, on the other hand; it tends to be brutal and to endanger the lives of inmates who live and work 'under the guns' of other convicts; and it leads to other abuses." Id. See id. at 373-76. Open barracks sleeping arrangements were found to encourage sexual attacks and other forms of violence. "The undisputed evidence is to the effect that within the last 18 months there have been 17 stabbings at Cummins, all but one of them taking place in the barracks, and four of them producing fatal results." Id. at 376 , quoting Holt v. Sarver, 300 F. Supp. 825, 831 (E.D. Ark. 1969).

84. 309 F. Supp. at 380 .

85. Id.

86. Id.

87. Id. at $378-79$.

88. Id. at 380 .

89. See, e.g., Novak v. Beto, 453 F.2d 66I (5th Cir. 197I), cert. denied, 409 U.S. 968 (1972); Sostre v. Rockefeller, 312 F. Supp. 863 (S.D.N.Y. 1970), rev'd in part, modified in part, aff'd in part sub nom. Sostre v. McGinnis, 442 F.2d 178 (2d Cir. I97r) (en banc), cert. denied, 404 U.S. I049, 405 U.S. 978 (1972).

90. The conditions facing pretrial detainees raise special problems because they amount to punishment of people who have not yet been convicted. Such conditions increasingly have been found unconstitutional under the mandate of Holt. See, e.g., Duran v. Elrod, 542 F.2d 998 (7th 
Holt's attention to the more typical and pervasive conditions that exist in many of the prisons throughout this country. ${ }^{91}$ In fact, $P$ ugh went considerably beyond Holt both by reaching a similar result without singling out any particularly important prison conditions ${ }^{92}$ and by moving toward a definition of the essential components of unconstitutional conditions of confinement. ${ }^{93}$

By finally concretizing the meaning of $H$ olt in a case truly involving the overall prison setting and carefully analyzing conditions likely to recur in American penitentiaries, $P$ ugh's holding that an aggregation of conditions of confinement violates the eighth amendment poses pressing new questions for both the judiciary and the state officials subject to federal court jurisdiction. Primary among these questions is how far the courts must go to remedy the pervasive conditions that contribute to a finding of unconstitutionality, especially in light of the limits that federalism places on how far they may go. Before reaching that question, however, both judges and prison officials must determine the types, degrees and number of prison conditions necessary to trigger the prohibition of the cruel and unusual punishment clause. Although the answer to this question is an equation replete with variables, ${ }^{94}$ there is one constant, suggested by $P u g h$

Cir. 1976); Miller v. Carson, 40 I F. Supp. 835, 865-67 (M.D. Fla. 1975); Rhem v. Malcolm, 377 F. Supp. 995 (S.D.N.Y.), enforcing $37 \mathrm{I}$ F. Supp. 594, 623 (S.D.N.Y.), aff'd and remandd, 507 F.2d 333 (2d Cir. 1974), on remand, 389 F. Supp. 964 (S.D.N.Y.), aff'd, 527 F.2d 104I (2d Cir. 1975); United States ex rel. Manicone v. Corso, 365 F. Supp. 576, 577 (E.D.N.Y. I973). See generally Note, Constitutional Limitations on the Conditions of Pretrial Detention, 79 Y ALE L.J. $94 \mathrm{I}$ (1970).

91. See note to supra.

92. The Pugb court, for example, only superficially mentioned the conditions that primarily motivated the decision in Holt: open dormitories, $406 \mathrm{~F}$. Supp. at 322-23, and the fact that some inmates performed supervisory tasks for prison personnel, id. at 325. See note 82 supra and acçompanying text.

93. Furthermore, unlike the instances of solitary confinement in which the courts frequently have employed the Holt standard, see notes 7 I \& 89 supra and accompanying texts, the conditions which were declared unconstitutional were not purposefully imposed. Rather, the defendants claimed that the Board of Corrections was incapable of alleviating the severe situation because of inadequate funding by the Alabama Legislature. The court responded that "a state is not at liberty to afford its citizens only those constitutional rights which fit comfortably within its budget." 406 F. Supp. at 330; accord, Holt v. Sarver, 309 F. Supp. 362, 385 (E.D. Ark. 1970), aff'd, $44^{2}$ F.2d 304 (8th Cir. $197 \mathrm{I}$ ): "Let there be no mistake in the matter; the obligation of the Respondents to eliminate existing unconstitutionalities does not depend upon what the Legislature may do, or, indeed, upon what Respondents may actually be able to accomplish. If Arkansas is going to operate a Penitentiary System, it is going to have to be a system that is countenanced by the Constitution of the United States." See also note 23 supra.

94. For example, one federal district judge, in contrasting unsanitary toilet facilities at the New Haven Correctional Center with those in another facility that had been declared unconstitutional in LaReau v. MacDougall, 473 F.2d 974, 977, 978 (2d Cir. 1972), cert. denied, 414 U.S. 878 (1973), confessed that "[a]s for toilet facilities, my constitutional calipers are not sufficiently refined to distinguish between a hole in the floor, controlled by a flush mechanism outside the cell and a bucket in the cell that a prisoner cannot empty as required." Osborn v. Manson, $359 \mathrm{~F}$. Supp. I107, I I I (D. Conn. 1973) (Newman, J.). 
and expressed elsewhere: "[T]he constitutionality of the conditions of confinement depends both on the details of those conditions and the duration of the confinement." 95

\section{Eleven foci of scrutiny in applying the doctrine: the second step.}

A careful reading of $P_{u g b^{96}}$ as well as the volume of cases that have applied Holt in the solitary confinement and pretrial detainee contexts reveals $I$ I aspects of institutional management that commonly comprise the conditions of confinement relevant to the constitutionality of a prison system and that provided the basis for the court's order in $P u g h .{ }^{97}$ Because in most cases no single factor will rise to the level of a constitutional violation, the court's remedy must address them all, as does the succeeding analysis.

Physical facilities. A major amount of recent judicial scrutiny of prisons has focused on the health and safety hazards as well as overwhelming inconvenience and annoyance caused by inoperative equipment and other substandard physical facilities. ${ }^{98}$ In addition to conditions that threaten imminent danger, the courts have looked at improper electrical wiring that results in insufficient illumination, ${ }^{99}$ inadequate and malfunctioning toilet and sewage systems that pose severe health problems, ${ }^{100}$ insufficient

95. Osborn v. Manson, 359 F. Supp. I107, I I I0 (D. Conn. I973); accord, LaReau v. MacDougall, 473 F.2d 974 (2d Cir. 1972), cert. denied, 414 U.S. 878 (I973); Sostre v. McGinnis, 442 F.2d I 78 (2d Cir. 197r) (en banc), cert. denied, 404 U.S. 1049, 405 U.S. 978 (1972); Wrighe v. McMann, 387 F.2d 519 (2d Cir. 1967), on remand, 321 F. Supp. 127 (N.D.N.Y. 1970), aff'd in part and rev'd in part, 460 F.2d I26 (2d Cir.), cert. denied, 409 U.S. 885 (1972).

Although in speaking of the latter, duration element, many courts appear to refer to conditions attendant to solitary confinement, this indicium remains relevant in scrutinizing the overall conditions of confinement. This relevance is especially visible in light of the great weight the courts have placed on the effect of such conditions as solitary punishment on the general quality of prison life. See notes I IO-I I infra and accompanying text.

96. For a discussion of the actual conditions found in Pugh, see text accompanying notes 1.4-23 supra.

97. Set gentrally Prigmore \& Crow, Is the Court Remaking the American Prison System?, 40 FED. ProB. 3, 5-7 (June 1976); Note, supra note $7 \mathrm{I}$, at 85I-64.

98. See, e.g., Gates v. Collier, 501 F.2d 129I, I300 (5th Cir. 1974) (exposed and frayed wiring, lack of adequate fire fighting equipment and defective water system creating a fire hazard); Pugh v. Locke, 406 F. Supp. 318,323 (M.D. Ala. I976) (electrical system inadequate); Miller v. Carson, 401 F. Supp. 835, 872 (M.D. Fla. 1975) (lack of central sprinkling system and limited ability, due to structural design, to evacuate jail occupants during a fire).

99. Ste, t.g., Pugh v. Locke, 406 F. Supp. 318, 323 (M.D. Ala. 1976) (inadequate lighting resulting in eye strain and fatigue).

100. See, e.g., Gates v. Collier, 50r F.2d I29r, I300 (5th Cir. 1974) (sewage system condemned by state health and pollution agencies); Pugh v. Locke, 406 F. Supp. 318, 323 (M.D. Ala. 1976) (one functioning toilet for a unit housing more than 200 inmates); Miller v. Carson, 410 F. Supp. 835, 87 I (M.D. Fla. 1975) (malfunctioning toilets causing unhealthy conditions); Jones v. Wittenberg, 323 F. Supp. 93, 96 (N.D. Ohio), supplemented, 330 F. Supp. 707 (N.D. Ohio 1971), aff'd sub nom. Jones v. Metzger, 456 F.2d 854 (6th Cir. 1972) (some inoperative toilets and leaking sewage pipes); note 94 supra. 
washing and showering appurtenances, ${ }^{101}$ and heating and ventilation inadequacies directly attributable to decrepit facilities. ${ }^{102}$

Overcrowding. Courts, including $P$ ugh, frequently have cited overcrowding as the one factor aggravating all other conditions of confinement and producing the most harmful physical and mental consequences. ${ }^{103}$ In addition to exacerbating other conditions, overcrowding may be directly responsible for the lack of a prison classification system ${ }^{104}$ or failure to protect inmates from assault by fellow prisoners. ${ }^{105}$

Absence of a classification system. The absence of a system of classifying the inmates, in fact, is an important yardstick by which courts have measured conditions of confinement. Establishment of such a system accomplishes four objectives. First, it properly separates pretrial detainees from convicted offenders. ${ }^{106}$ Second, it segregates the physically or mentally ill from the general inmate population. ${ }^{107} \mathrm{Third}$, it removes misdemeanants and juvenile offenders from potentially destructive contact with felony offenders. ${ }^{108}$ Finally, it sequesters violent inmates from young and weak prisoners prone to assault or sexual abuse. ${ }^{109}$

Isolation and segregation cells. As noted earlier, the courts historically have given special attention to cases involving solitary confinement. ${ }^{110}$ In addition, the courts since Holt have examined these special tools of prison

I0I. See, e.g., Gates v. Collier, 50I F.2d I29I, r300 (5th Cir. 1974) (80 men required to use 3 wash basins consisting of oil drums cut in half); Pugh v. Locke, 406 F. Supp. 318, 323 (M.D. Ala. 1976) (some showers could not be turned off and continually dripped or even poured water; no hot running water for substantial periods of time); Jones v. Wittenberg, $323 \mathrm{~F}$. Supp. 93, 95-96 (N.D. Ohio), supplemented, 330 F. Supp. 707 (N.D. Ohio I971), aff'd sub nom. Jones v. Metzger, 456 F.2d 854 (6th Cir. 1972) (water temperature incapable of being controlled and sometimes scalding).

I02. See, e.g., Pugh v. Locke, 406 F. Supp. 318, 323 (M.D. Ala. 1976) (inadequate heating and ventilation); Miller v. Carson, 40 I F. Supp. 835, 872 (M.D. Fla. I975) (fluctuating temperatures and poor ventilation posing constant health hazard); Jones v. Wittenberg, $323 \mathrm{~F}$. Supp. 93, 95 (N.D. Ohio) (no ventilation), supplemented, 330 F. Supp. 707 (N.D. Ohio 1971), aff' $d$ sub nom. Jones v. Metzger, 456 F.2d 854 (6th Cir. 1972).

I03. See, e.g., Pugh v. Locke, 406 F. Supp. 318, 322, 325 (M.D. Ala. 1976); Miller v. Carson, 40I F. Supp. 835, 873-74 (M.D. Fla. 1975); McCray v. Sullivan, 399 F. Supp. 271, 275 (S.D. Ala. 1975); note I5 supra and accompanying text.

104. See text accompanying notes I6-18 supra; text accompanying notes 106-09 infra.

105. See text accompanying note 129 infra.

I06. See, e.g., Jones v. Wittenberg, 330 F. Supp. 707, 717 (N.D. Ohio 1971), aff'd sub

nomr. Jones v. Metzger, 456 F.2d 854 (6th Cir. 1972).

107. See, e.g., Pugh v. Locke, 406 F. Supp. 318, 324 (M.D. Ala. 1976); Miller v. Carson,

4 Io F. Supp. $835,874-75$ (M.D. Fla. 1975); text accompanying notes I7-18 supra. I08. See, e.g., Miller v. Carson, 401 F. Supp. 835, 874-75 (M.D. Fla. 1975).

109. See, e.g., Gates v. Collier, 501 F.2d 129r, 1308 (5th Cir. 1974); Pugh v. Locke, 406 F. Supp. 318, 324 (M.D. Ala. 1976).

I IO. See note 7 I supra and accompanying text; notes I66-70 infra and accompanying text. 


\section{discipline as important aspects of the more ubiquitous conditions of confinement. ${ }^{111}$}

Medical facilities and treatment. The availability and quality of medical treatment has been a key element in most judicial examinations of conditions of confinement. Although courts have considered the number of medical personnel on call $^{112}$ and the existence of adequate medical facilities, ${ }^{113}$ the actual or potential spread of contagion ${ }^{114}$ and specific instances of inadequate attention to physical or mental health ${ }^{115}$ have been of special concern. Moreover, deprivation of basic medical needs has been declared per se violative of the eighth amendment. ${ }^{116}$

I I I. See Gates v. Collier, 50I F.2d I29I, I304-05 (5th Cir. 1974); Holt v. Sarver, 309 F. Supp. 362,378 (E.D. Ark. I970), aff'd, $44^{2}$ F.2d 304 (8th Cir. I97I); note 19 supra and accompanying text.

In Pugh v. Locke, 406 F. Supp. 318, 327-28 (M.D. Ala. 1976), for example, the court stated that " $[t]$ he indescribable conditions in the isolation cells required immediate action to protect inmates from any further torture by confinement in those cells. As many as six inmates were packed in four foot by eight foot cells with no beds, no lights, no running water, and a hole in the floor for a toilet which could only be flushed from the outside. The infamous Draper 'doghouse' is a separate building, locked from the outside, with no guard stationed inside. Inmares in punitive isolation received only one meal per day, frequently without utensils. They were permitted no exercise or reading material and could shower only every I I days. Punitive isolation has been used to punish inmates for offenses ranging from swearing at guards and failing to report to work on time, to murder."

I12. See, e.g., Gates v. Collier, 501 F.2d 1291, I303 (5th Cir. 1974) (medical facilities grossly understaffed); Miller v. Carson, 40 I F. Supp. 835, 876-77 (M.D. Fla. I975) (physician available only one-half day a week; only four nurses employed, resulting in long period of time with virtually no medical personnel on call; no psychiatrists or psychologists available); Jones v. Wittenberg, 323 F. Supp. 93, 97 (N.D. Ohio), supplemented, 330 F. Supp. 707 (N.D. Ohio I97 I), aff'd sub nom. Jones v. Metzger, 456 F.2d 854 (6th Cir. 1972) (physician available 2 or 3 afternoons a week but frequently could not be reached; dentist only occasionally available; nurse on duty during daytime only); note 1 I 6 infra.

I 13. See, e.g., Miller v. Carson, 40 I F. Supp. 835,878 (M.D. Fla. I975) (size of medical clinic inadequate; equipment antiquated and useless); Jones v. Wittenberg, 323 F. Supp. 93, 97 (N.D. Ohio), supplemented, 330 F. Supp. 707 (N.D. Ohio 1971), aff'd sub nom. Jones v. Metzger, 456 F.2d 854 (6th Cir. 1972) (primitive health facilities).

I 14. See, e.g., Gates v. Collier, 501 F.2d I29I, I300 (5th Cir. 1974) (inmates with contagious diseases found in general prison population); Miller v. Carson, 40I F. Supp. 835, 877-78 (M.D. Fla. I975) (inmates diagnosed with possible smallpox, chicken pox, impetigo, infectious hepatitis, and mumps in contact with general population).

I I 5. See, e.g., Estelle v. Gamble, 97 S. Ct. 285 (1976); Bishop v. Stoneman, 508 F. 2d 1224, 1225-1226 (2d Cir. 1974); Williams v. Vincent, 508 F.2d 54I (2d Cir. I974); Corby v. Conboy, 457 F.2d 251, 254 (2d Cir. 1972); Martinez v. Mancusi, 443 F.2d 921, 924 (2d Cir. 1971); United States ex rel. Hyde v. McGinnis, 429 F.2d 864, 867 (2d Cir. 1970); Pugh v. Locke, 406 F. Supp. 318, 329 (M.D. Ala. 1976); Miller v. Carson, 40 I F. Supp. 835, 878 (M.D. Fla. 1975). See generally Robbins \& Herman, Litigating Without Counsel: Faretta or for Worse, 42 BROOKLYN L. REV. 629, 646-48 (I976).

I 16. See Pugh v. Locke, 406 F. Supp. 318, 329 (M.D. Ala. 1976). Prior to Pugh, the District Court for the Middle District of Alabama had held that the lack of medical care in the Alabama prisons violated the eighth amendment. Newman v. Alabama, 347 F. Supp. 278 (M.D. 
Food service. Courts also have focused their attention on unsanitary kitchen facilities, ${ }^{117}$ food handling procedures ${ }^{118}$ and the nutritional content of the food itself. ${ }^{119}$ Less frequently, courts have examined the variety and quantity of the meals. ${ }^{120}$

Personal bygiene and sanitation. Matters of hygiene and sanitation dominated the courts' concern in assessing the conditions of confinement. Any discussion of physical facilities, ${ }^{121}$ overcrowding, ${ }^{122}$ medical facilities and treatment, ${ }^{123}$ food service, ${ }^{124}$ and particularly isolation and segregation cells $^{125}$ generally has hinged on the issue of hygiene and sanitation. With regard to personal hygiene, the courts have looked to the availability of

Ala. 1972), aff'd in part, 503 F.2d 1320 (5th Cir. 1974), cert. denied, 42 I U.S. 948 (1975). The evidence in that case showed, amongst many other horrors, that a 19 -year-old with an extremely high fever who was diagnosed as having acute pneumonia was left unobserved and allowed to take cold showers at will for 2 days before his death; a quadriplegic with bedsores infested with maggors was bathed and had his bandages changed only once in the month before his death; a geriatric inmate who had suffered a stroke was made to sit each day on a wooden bench, so that he would not soil his bed-he frequently fell onto the floor, and his legs became swollen from a lack of circulation, necessitating the amputation of a leg the day before his death. $1 d$. at 285 . The court entered a comprehensive order designed to remedy each specific abuse proved at trial, and to establish additional safeguards, so that the medical program at the Alabama prisons would never again regress to its past level of inadequacy. $1 d$. at $286-88$. But the court noted in $P$ ugh that at least some of Neuman's order had not been carried out 4 years later. $406 \mathrm{~F}$. Supp. at 33.

On the operation and management of Alabama's state mental institutions, see Wyatt v. Stickney, 325 F. Supp. 781 (M.D. Ala. 1971), enforced, 344 F. Supp. 373, 344 F. Supp. 387 (M.D. Ala. 1972), modified sub nom. Wyatt v. Aderholt, 503 F.2d r 305 (5th Cir. 1974) (affirming constitutional "right to treatment"). See also note 204 infra.

I 17. See, e.g., Pugh v. Locke, 406 F. Supp. 318,323 (M.D. Ala. 1976) (food storage units infested with insects; mechanical dishwashers failed to provide minimum temperature required for sanitation).

I 18. See, e.g., Pugh v. Locke, 406 F. Supp. 3 18, 323 (M.D. Ala. 1976) (food personnel untrained and did not follow sanitation procedures); Miller v. Carson, 401 F. Supp. 835, 880 (M.D. Fla. 1975) (food served and handled by uncertified corrections officers and trusties); Holt v. Sarver, 309 F. Supp. 362, 380 (E.D. Ark. 1970), aff'd, $44^{2}$ F.2d 304 (8th Cir. 1971) (unsanitary conditions attributed to trusties in charge of kitchen).

II . See, e.g., Pugh v. Locke, 406 F. Supp. 318, 323 (M.D. Ala. 1976) (unwholesome food); Miller v. Carson, 40 I F. Supp. 835,879 (M.D. Fla. 1975) (deficient diet failing to meet nutritional needs); Jones v. Wittenberg, 323 F. Supp. 93, 96 (N.D. Ohio), supplementtd, $33 \circ$ F. Supp. 707 (N.D. Ohio 197I), aff'd sub nom. Jones v. Metzger, 456 F.2d 854 (6th Cir. 1972) (2000 calories per day ordered provided).

I 20. See, e.g., Pugh v. Locke, 406 F. Supp. 318, 323 (M.D. Ala. 1976) (unappetizing food); Miller v. Carson, 40 I F. Supp. 835, 88 I (M.D. Fla. 1975) (only two meals per day for all inmates except trusties); Jones v. Wittenberg, 323 F. Supp. 93,96 (N.D. Ohio), supplemented, 330 F. Supp. 707 (N.D. Ohio $197 \mathrm{r}$ ), aff d sub nom. Jones v. Metzger, 456 F.2d 854 (Gth Cir. 1972) (meals qualitatively and quantitatively inadequate).

121. See notes 98-102 supra and accompanying text.

122. See notes 103-05 supra and accompanying text.

123. See notes i 12-I 6 supra and accompanying text.

124. See notes i 17-20 supra and accompanying text.

125. See notes IIO-I I supra and accompanying text. 
basic supplies for maintaining routine health and cleanliness, ${ }^{126}$ while adequate sanitation in the prison community has been measured by the incidence of vermin ${ }^{127}$ and general findings of filth caused by improper housekeeping. ${ }^{128}$

Protection from violence. Inevitably, one of the more serious problems of prison life is the repeated occurrence of violent and sexual attacks among the prison population. Although the victim may have a cause of action for occasional violence and sexual abuse, a prisoner now also "has a right, secured by the eighth and fourteenth amendments, to be reasonably protected from constant threat of violence and sexual assault by his fellow inmates, and he need not wait until he is actually assaulted to obtain relief." 129

Prison personnel. Courts often have cited the insufficient number and poor quality of staff members as an important factor contributing to other impermissible conditions by subjecting inmates to inadequate protection and supervision. ${ }^{130}$

Rehabilitation programs. As a general rule, courts have not held the lack of rehabilitation programs-educational, vocational, work, or recreational-to be per se violative of the cruel and unusual punishment clause. ${ }^{131}$ But recent decisions have considered this factor in evaluating the overall condition of confinement. ${ }^{132}$

126. Ste, e.g., Pugh v. Locke, 406 F. Supp. 318, 323 (M.D. Ala. 1976) (no provision of toothpaste, toothbrushes, shampoo, shaving cream, razors, or combs).

127. Sit, e.g., Pugh v. Locke, 406 F. Supp. 318, 323 (M.D. Ala. 1976) (infestations of body lice, roaches, fies, mosquitoes, and other vermin); Commonwealth ex rel. Bryant v. Hendrick, 444 Pa. 83, 94, 280 A.2d I IO, II5 (1971) (cells infested with cockroaches and rats).

128. Set, e.g., Pugh v. Locke, 406 F. Supp. 318, 323 (M.D. Ala. 1976) (Alabama's penal institutions termed "filthy"); Miller v. Carson, 40r F. Supp. 835, 869 (M.D. Fla. 1975) (vomitus, urine and feces on floor).

129. Woodhous v. Virginia, 487 F.2d 889, 890 (4th Cir. I973); accord, Finney v. Arkansas Bd. of Correction, 505 F.2d I94, 20 I (8th Cir. I974); Pugh v. Locke, 406 F. Supp. 318, 324 (M1.D. Ala. I976) (daily occurrences of robbery, rape, extortion, and assault). See generally Plothin, Surviving Justice: Prisoners' Rights to be Free From Physical Assault, 23 CLEV. ST. L. REv. 387 (1974).

130. See, e.g., Pugh v. Locke, 406 F. Supp. 318, 325 (M.D. Ala. 1976) (minimum of 692 guards needed but only 383 employed); Holt v. Sarver, 309 F. Supp. 362, 373 (E.D. Ark. 1970), aff'd, 442 F.2d 304 (8th Cir. I97 I) (35 "free world" personnel in charge of almost 1,000 inmates).

I 3x. E.g., Holt v. Sarver, 309 F. Supp. 362, 379 (E.D. Ark. 1970), aff'd, 442 F.2d 304 (Sth Cir. 197I) ("'T] his Court knows that a sociological theory or idea may ripen into constitutional law; many such theories and ideas have done so. But, this Court is not prepared to say that such a ripening has occurred as yet as far as rehabilitation of convicts is concerned.").

132. One of the more important aspects of Pugh v. Locke, 406 F. Supp. 3 I8 (M.D. Ala. 1976), is its emphasis on the absence or inadequacy of rehabilitation programs. See id. at 325-27, 330. In Holt v. Sarver, 309 F. Supp. 362 (E.D. Ark. 1970), aff'd, 442 F.2d 304 (8th Cir. 197I), the court developed a concept that might be called "dehabilitation": "The absence of an affirma- 
Other prisoners' rights. Most affirmative prisoners' rights claims have raised assorted allegations of constitutional violation, including racial segregation, ${ }^{133}$ unreasonable searches and seizures, ${ }^{134}$ denial of first amendment freedoms, ${ }^{135}$ and lack of procedural due process in disciplinary proceedings, ${ }^{136}$ with the court deciding the case on other than eighth amendment grounds. Still, violations of other constitutional guarantees have contributed to ultimate findings of cruel and unusual punishment. ${ }^{137}$

\section{A consistent definition and application of the "totality of conditions" doctrine: a step not yet taken.}

Pugh, Holt and similar cases clearly point the direction of a new doctrinal approach to eighth amendment adjudication in the prison context. They begin with the insight that the lack of a singular unconstitutional condition of confinement should not dispose of the question of a prison's compliance with the ban on cruel and unusual punishment; the totality of the conditions of confinement must be examined both in its detail and, when relevant, in its duration. Next, these cases embody I I relatively general questions that a reviewing court should ask about the conditions of the challenged prison system focusing particularly on the adequacy of medical treatment, hygiene, sanitation, and means of prevent-

tive program of training and rehabilitation may have constitutional significance where in the absence of such a program conditions and practices exist which actually militate against reform and rehabilitation." Id. at 379; accord, Pugh v. Locke, 406 F. Supp. 318, 330 (M.D. Ala. 1976). See notes $158-65$ infra and accompanying text.

133. See, e.g., Toles v. Katzenbach, 385 F.2d 107 (9th Cir. I967); Lamar v. Kern, 349 F. Supp. 222 (S.D. Tex. I972); United States v. Wyandotte County, 343 F. Supp. I I89 (D. Kan. I 972), rev'd, 480 F.2d 969 (Ioth Cir.), cert. denied, 4 I 4 U.S. I068 (1973); Rentfrow v. Carter, 296 F. Supp. 301 (N.D. Ga. 1968); Wilson v. Kelley, 294 F. Supp. I005 (N.D. Ga.), aff'd per curiam, 393 U.S. 266 (I968); Washington v. Lee, 263 F. Supp. 327 (M.D. Ala. 1966), aff'd mem:, 390 U.S. 333 (r968).

I 34. See, e.g., Lanza v. New York, 370 U.S. I 39 ( 1962 ) (seizure of conversations); Hodges v. Klein, 4I2 F. Supp. 896 (D.N.J. I976) (strip searches); Travers v. Paton, 26I F. Supp. I IO (D. Conn. I966) (deprivation of privacy); Moore v. People, 17 I Colo. 338, 467 P.2d 50 (1970) (seizure of items from cell).

I35. See, e.g., Saxbe v. Washington Post Co., $4{ }^{17}$ U.S. 843 (1974) (right to press and other media interviews); Pell v. Procunier, $4 \mathrm{I} 7$ U.S. 817 (I974) (same); Procunier v. Martinez, 416 U.S. 396 (1974) (right to correspondence); Cruz v. Beto, 405 U.S. 319 (1972) (right to exercise religion); Berrigan v. Norton, 45I F.2d 790 (2d Cir. 197I) (right to publish manuscripts); Barnett v. Rodgers, 4 Io F.2d 995 (D.C. Cir. 1969) (right to observe religious dietary laws). See generally Comment, Black Muslims in Prison: Of Muslim Rites and Constitutional Rights, 62 Colum. L. Rev. 1488 ( $\mathrm{I}_{9} \mathrm{G}_{2}$ ). Of course, first amendment rights are not limited to speech, assembly and religion. On prisoners' access to the courts, see, e.g., Bounds v. Smith, $97 \mathrm{~S}$. Ct. I 49 I (1977); Johnson v. Avery, 393 U.S. 483 (I969).

I 36. See, e.g., Baxter v. Palmigiano, $96 \mathrm{~S}$. Ct. I55 I (197.6); Wolff v. McDonnell, 418 U.S. 539 (1974).

137. See generally Sostre v. McGinnis, 442 F.2d 178 (2d Cir. 1971) (en banc), cert. denicd, 404 U.S. 1049 , 405 U.S. 978 (1972). 
ing violence. But having isolated these numerous and common features of prison institutions that together may violate the Constitution, the courts have failed to elucidate a precise formula or even reflect a clear pattern in converting their variegated findings into eighth amendment holdings. Nonetheless, several relatively settled conclusions may be drawn from the doctrinal development. First, the "totality of conditions" approach, although perhaps no less elusive than the concepts of humanity and penological justification that characterized the three more traditional eighth amendment approaches discussed earlier, ${ }^{138}$ clearly responds more adequately to the expansive inquiry necessitated in examining the cruelty and unusualness of punishment in American prisons. Further, plaintiff prisoners preparing causes of action under the eighth amendment would be well advised to employ a multifaceted presentation to take advantage of the fact that under the Holt-Pugh approach a combination of unsatisfactory conditions 'will be more likely to succeed than will any single factor. Finally, and most importantly, should the plaintiff succeed, the federal district court must face the complex problem of fashioning a workable means, within the confines of federalism, of enforcing minimal constitutional standards for conditions of confinement against a large state agency.

\section{REMEDYING UNCONSTITUTIONAL CONDITIONS OF CONFINEMENT: IMPLICATIONS OF MINIMAL CONSTITUTIONAL STANDARDS}

The federal district courts have drawn upon venerable forms of equitable relief and developed more imaginative and sweeping ones in response to the cruel and unusual punishment clause's new application to the totality of prison conditions. Even before $P u g h$ advanced the "totality of conditions" approach to its logical conclusion, the availability of class actions and the need to respond to specific unconstitutional prison conditions had prompted a wide range of equitable responses from the courts. Under one common injunctive technique in the prison setting, prison officials must present the court with a plan for correcting the infirmities of the institution. ${ }^{139}$ Another available method uses mediation to achieve a compromise between standards desired by the inmates and the feasibility of their implementation by prison administrators and personnel. ${ }^{140}$ Courts also

138. See text accompanying notes $63-76$ supra.

I39. See, e.g., Holt v. Sarver, 309 F. Supp. 362, 383-85 (E.D. Ark. 1970), aff'd, 442 F.2d 304 (8th Cir. 197I); SaMarion v. McGinnis, 253 F. Supp. 738, 741 (W.D.N.Y. I 966).

140. See, e.g., Morris v. Travisono, 3 IO F. Supp. 857 (D.R.I. I970) (entire new set of regulations drafted after arms-length bargaining by counsel conducted under the auspices of the court). See generally Note, Bargaining in Correctional Institutions: Restructuring the Relation between the Inmate and the Prison Authority, 8I YALE L.J. 726 (1972). Another alternative is that of the penal ombudsman. See generally W. Gellhorn, When Americans Complain: Governmental 
have closed or threatened to close various institutions, ${ }^{141}$ but more commonly they have preferred to retain jurisdiction over the case and to require periodic progress reports. ${ }^{142}$

In Pugh v. Locke, ${ }^{143}$ however, in congruence with the wide range of factors contributing to the holding of unconstitutionality, the federal court interpreted its powers broadly to allow it to establish both minimum constitutional standards and a citizen's panel to monitor and supervise all penal reform in the State of Alabama. ${ }^{144}$ Just as Pugh embodied the most far-ranging consideration of confinement conditions in arriving at its holding, this remedial action constituted the most expansive intrusion yet by a federal court into the management of state penal facilities. The remainder of this Part of the Article considers the propriety and desirability of this interposition of federal power into state prison affairs.

\section{A. Pugh v. Locke: The Questionable Constitutional Bases for Its Minimum Standards}

The minimum constitutional standards formulated by Chief District Judge Frank M. Johnson in Pugh v. Locke ${ }^{145}$ are unique in many respects. For example, in only a few instances did the court allow prison officials significant latitude to develop their own remedial plans for the reformation of the Alabama prison system. ${ }^{146}$ Instead, the court's standards categorically dictated not only the requisite constitutional reforms but also the mandatory implementation method. ${ }^{147}$ Although some of the standards

Grievance Procedures in Nine Countries (1966); Tibbles, Ombudsmen for American Prisms, 48 N.D. L. Rev. 383 (1972); Verkuil, The Ombudsman and the Limits of the Adversary System, 75 COLUM. L. ReV. 845 (I975).

14x. See, e.g., Pugh v. Locke, 406 F. Supp. 318, 33 (M.D. Ala. 1976) (failure to comply with minimum standards "will necessitate the closing of those several prison facilities"); Rhem v. Malcolm, 389 F. Supp. 964, 966 (S.D.N.Y. 1975), aff'd and remanded, 507 F.2d ro4 I (2d Cir. 1975) (ordering jail closed within 30 days if conditions not remedied); Holt v. Sarver, $309 \mathrm{~F}$. Supp. 362, 383 (E.D. Ark. 1970), aff'd, 442 F.2d 304 (8th Cir. 1971) (" [U]nless conditions at the Penitentiary farms are brought up to a level of constitutional tolerability, [they] can no longer be used for the confinement of convicts.").

142. See, e.g., Brenneman v. Madigan, 343 F. Supp. I28, I33 (N.D. Cal. 1972) (regular reports on efforts to comply with district court's order). In Pugh v. Locke, 406 F. Supp. 318,332 (M.D. Ala. 1976), the court expressly retained jurisdiction.

I 43. 406 F. Supp. 318 (M.D. Ala. 1976).

r 44. See text accompanying notes 24-27 supra.

145. 406 F. Supp. 318 (M.D. Ala. 1976).

146. Id. Compare id. with note 139 supra and accompanying text. The Pugh order mandated that the defendants file a classification plan for all inmates, which was to correspond with definitive guidelines established by the court. $406 \mathrm{~F}$. Supp. at 333. The order further required the defendants to contract with the University of Alabama Department of Correctional Psychology to assist in the implementation of the plan. Id.

I 47.406 F. Supp. at 332-35. 
referred to established Supreme Court guidelines, ${ }^{148}$ the court in some instances forged new law, as in requiring that "[e]very inmate, prior to release, . . . be afforded the opportunity to participate in some transitional program designed to aid in his or her re-entry into society."149 Further, the court established and delegated extensive authority to a 39-member Human Rights Committee. ${ }^{150}$ The court empowered the committee to inspect records and facilities, to interview inmates and to hire a staff. ${ }^{151}$ But the court described the committee's function as simply "to monitor implementation of the standards set forth in Appendix A to this decree." 152

In assessing Pugh's minimum standards, it is immediately apparent that many lack specific constitutional foundation. Even as a policy matter, the efficacy of the measures proposed is not clear. On the one hand, the requirement in $P u g h$ that every inmate be furnished a storage locker and lock $^{153}$ might alleviate the perennial problems of thievery among inmates and illegal confiscation or destruction of inmate property by prison officials ${ }^{154}$ and, in addition, might enhance an inmate's sense of personal dignity by providing a secure area for private possessions. ${ }^{155}$ On the other hand, prison authorities might argue that such a policy would encourage the possession of contraband. ${ }^{156}$ But regardless of the relative strength of these policy arguments, in this one arguably minor but typical instance the court clearly has moved from conventional notions of alleviation of cruel and unusual punishment to what typically qualifies as the nonconstitutional and extrajudicial realm of prison reform. ${ }^{157}$

148. Examples are the standards relating to disciplinary proceedings, id. at 332 , citing Wolff v. MicDonnell, 4 I 8 U.S. 539 (I974), and correspondence and visitation, 406 F. Supp. at 334, citing Procunier v. Martinez, 416 U.S. 396 (I974).

149. $406 \mathrm{~F}$. Supp. at 335 ; see notes $158-65$ infra and accompanying text.

150. 406 F. Supp. at $33 \mathrm{r}$.

I5I. Id. at 33 I-32. Payment for the Committee members' services and reimbursement for travel and expenses were to be treated in the same manner as for members of the Alabama Board of Corrections. Id. at $33 \mathrm{I}$.

152. Id. at $33 \mathrm{I}$. The court also authorized the committee to monitor implementation of the court's earlier order in Newman v. Alabama, 349 F. Supp. 278 (M.D. Ala.), aff'd in part, 503 F.2d I 320 (5th Cir. 1974), cert. denied, 421 U.S. 928 (1975), discussed in note I 6 supra. The committee was authorized "to take any action reasonably necessary to accomplish its function." 406 F. Supp. at 332.

I 53.406 F. Supp. at 334 .

154. See generally Robbins \& Herman, supra note 115 , at 656-57 n. I62.

155. See generally Schwartz, Deprivation of Privacy as a "Functional Prerequisite": The Case of the Prison, 63 J. CRIM. L.C. \& P.S. 229 (1972). For judicial commentary on the inmate's privacy right, see, e.g., Hodges v. Klein, $4 \mathrm{I} 2$ F. Supp. 896 (D.N.J. I976) (strip searches); Travers v. Paton, 26I F. Supp. I Io (D. Conn. 1966) (media at parole hearing).

156. See Moore v. People, 17 I Colo. 338, 467 P.2d 50 (1970).

157. The Pugh standards relating to food service highlight the court's attention to arguably nonconstitutional detail. Recently, the courts have held that the constitutional prohibition 
The court's order regarding rehabilitation provides another illustration of its unorthodox approach to the federal judicial function. Acknowledging that "courts have thus far declined to elevate a positive rehabilitation program to the level of a constitutional right," 158 the $P$ ugb court nevertheless adroitly pressed the concept of "dehabilitation" into a constitutional mold, ${ }^{159}$ noting that the lack of such programs increases the likelihood of future confinement and thus "defeat[s] the goal of rehabilitation, which prison officials have set for their institutions." 160 Pursuant to Chief Judge Johnson's order, prison officials must assign every inmate "a meaningful job on the basis of [his] abilities and interests" 161 and provide prisoners with the opportunity to receive a basic education, participate in vocational training programs designed to teach a marketable skill and attend a "transitional program" prior to release. ${ }^{162}$ The court further ordered that every prison in Alabama employ a qualified college graduate as recreational director and make space available for inmates to engage in hobbies. ${ }^{163}$

Again, the outlines and detail of such programs, although perhaps desirable, have no firm root in the Constitution. Prior to Pugh, courts had

against cruel and unusual punishment requires every inmate to be fed adequately. See, e.g., Landman v. Royster, 333 F. Supp. 62 I, 647 (E.D. Va. I97 I), enforced, 354 F. Supp. 1302 (E.D. Va. 1973). But the Pugh court mandated three meals per day with "proper eating and drinking utensils," a "food service supervisor for each institution" with a minimum of bachelor's level training in "dietetics or its equivalent" and a "registered dietician" to act as a "nutrition consultant" for the Board of Corrections, 406 F. Supp. at 334. Obviously, the eighth amendment on its face does not address the issue of prison cuisine.

Few would doubt that the $P$ ugh food service standards are beneficial and important. "The inmate's food, besides providing the nutrients needed for optimum health, should be plentiful and well served. The food service program is of fundamental importance in the maintenance of good morale." American Correctional Association, Manual of Correctional StanDARDS 444 (3d ed. 1966). But it is not so clear that the eighth amendment should bar a prison gruel that is nutritionally adequate yet monotonous in taste, color and variety, prepared by a short-order cook and served twice daily. That is, on its face, the eighth amendment does not prohibit gruel and unusual punishment. Note that the court later modified the order to require two meals per day, rather than three. James v. Wallace, Civil No. 74-203-N (M.D. Ala., Mar. 5. 1976).

The court further ordered that "[a]Il kitchen employees shall be trained in the handling of food and those who assist in the preparation of food shall receive training in food preparation," and that "[e]ach inmate who requires a special diet for reasons of health or religion shall be provided a diet to meet his or her individual need." $406 \mathrm{~F}$. Supp. at 334. A motion to modify this latter requirement was denied. James v. Wallace, Civil No. 74-203-N (M.D. Ala., Mar. 5, 1976). See generally notes I 1-20 supra and accompanying text.

No doubt some authorities would argue that any prison reform is beyond the scope of any court's function. See note 43 supra and accompanying text. See generally Comment, supra note $4 \mathrm{I}$.

I58. $406 \mathrm{~F}$. Supp. at 330. See notes 13 I-32 supra and accompanying text.

159. See note I 32 supra.

r60. 406 F. Supp. at 330 .

I6I. Id. at 335 .

I62. Id.

I63. Id. 
gone no further than to hold that a penal system violates the eighth amendment if it operates "in such a manner that it impedes an inmate's ability to attempt rehabilitation, or simply to avoid physical, mental or social deterioration." 164 Thus, the $P$ ugh requirement arguably is as much an optimum preference as a minimum constitutional standard. ${ }^{165}$

No aspect of conditions of prison confinement is as disconcerting as the problem of overcrowding. ${ }^{166}$ Prison officials are obliged to supervise a burgeoning inmate population in facilities that typically are aged and inadequate. ${ }^{167}$ Chief Judge Johnson not only prohibited prisons from housing additional inmates until the population did not exceed the design capacity; ${ }^{168}$ he also ordered the state to furnish each resident with at least 60 square feet of living space. ${ }^{169}$ In that this "minimum constitutional requirement" surpasses the demands of several reform-minded model penal standards, ${ }^{170}$ it may outstrip the dictates of desirability, and surely outdistances any past concept of "constitutional requirement."

As his order's approach to such issues as footlockers, rehabilitation and living space indicates, Chief Judge Johnson did not hesitate to carry his equitable remedial powers at least to the periphery both of the mandate of the eighth amendment and of the overall role of federal judges in adjudicat-

I64. Id. at 330, citing Holt v. Sarver, 309 F. Supp. 362, 379 (E.D. Ark. 1970), aff'd, 442 F.2d 304 (8th Cir. 1971).

I 65. "[A] prison system that would be excellent from the point of view of a modern prison administrator may not be required by the provisions of the Constitution with which the Court is concerned." Holt v. Sarver, 309 F. Supp. 362, 369 (E.D. Ark. 1970), aff'd, 442 F.2d 304 (8th Cir. 1971).

I66. See notes I5 \& 103 supra and accompanying texts.

167. See note ro supra.

I68. 406 F. Supp. at 332; see note I5 supra.

r69. $406 \mathrm{~F}$. Supp. at 332 . The court further ordered prison administrators to equip each isolation cell with a toilet that could be flushed from the inside and a sink with hot and cold running water, and to meet United States Public Health Service Standards. Id. Each inmate also was to be allowed to bathe every other day, to receive the same toilet articles and linens as provided to the general inmate population, to have 30 minutes of outdoor exercise per day, and to have a medical examination every third day by both a physician and a "qualified mental health care professional." Id. The order regarding plumbing facilities was modified to the extent that they could be omitted from some of the punitive isolation cells for the confinement of inmates who consistently misused such facilities. James v. Wallace, Civil No. 74-203-N (M.D. Ala., Mar. 5, 1976). With regard to living conditions generally, inmates were to be provided with toothbrushes, toothpaste, shaving cream, razors, razor blades, soap, shampoo, a comb, clean clothing, bed linen, towels, beds off the floor, and clean mattresses and blankets. $406 \mathrm{~F}$. Supp. at 334. A subsequent order removed shampoo from this list of personal hygiene items. James v. Wallace, Civil No. 74-203-N (M.D. Ala., Mar. 5, 1976).

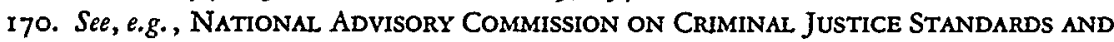
GonLs, CORRECTIONS 34 (1973) (inmate's cell should be of "adequate size"); NAtional CounCIL on Crime and Delinguency, A Model ACt for the Prótection of Rights of PRISONERS, $\int \mathrm{I}$, at IS (1972) ("not less than fifty square feet of floor space in any confined sleeping area"). 
ing claims against state agencies. Yet, because he used the "totality of conditions" approach, which bases the right to relief on a conglomeration of I I considerations, Chief Judge Johnson was forced into adopting a remedy that responded to all I I considerations - a remedy that inevitably would be far ranging. It may seem ironic, nonetheless, that inmateplaintiffs who are unable to make out a constitutional cause of action based on any one prison condition in effect may receive the same relief as if they had made out and succeeded on I I such claims; it only adds to the irony that such inmates also may be entitled to a plethora of remedies that require significantly more intensive and constitutionally less obvious forms of federal court supervision over state agencies than the remedies available under any one such claim would require.

One answer to this argument is that insofar as the eighth amendment's ban on cruel and unusual punishment covers the totality of prison conditions, the remedy for violations of that ban necessarily must intrude in that same totality. Moreover, for at least two reasons, the remedy probably will not succeed unless it attempts significantly and quite specifically to cure each of the I I offending conditions, even if, theoretically, a slighter improvement on all I I fronts would have removed the constitutional infirmity of the overall conditions of confinement. First, an effort at piecemeal or modest improvement in conditions is not likely to result in an overall improvement; ordering resources shifted to repair the leaking plumbing in one cellblock simply may result in neglect of the plumbing problems in other cellblocks. Further, in an effort to avoid overly detailed guidelines, a court order often may succumb to vague and overly broad principles of conduct that are easily ignored, evaded or misconstrued. Despite the lack of an immediately apparent constitutional basis, therefore, the remedy for a "totality of conditions" violation of the eighth amendment may have to exceed in scope and detail the sum of the remedies for any individual condition's violation.

\section{B. Answering the Federalism Critique of Federal Judicial Supervision of State Penal Administration}

Even assuming the constitutional propriety of the degree of constitutional relief afforded in Pugh, Rizzo v. Goode ${ }^{171}$ suggests that the federalism concerns may remove the power of the federal courts to afford that relief. In fact, on the basis of its ambitious remedy, $P_{u g} b$ at first appears to be a prime candidate for reversal under the federalism policy of Rizzo. Certainly the Pugh court's order is far more intrusive than the one overturned in Rizzo, which merely ordered the Philadelphia Police Department to draw

171. 423 U.S. 362 (1976), discussed in text accompanying notes $35-40$ supra. 
up certain guidelines and submit them to the court. ${ }^{172}$ Indeed, the Pugh standards are so detailed that they preclude any significant input on the part of prison officials. ${ }^{173}$ Moreover, Pugh, like Rizzo, involved federal court intervention in certain internal affairs of a state agency that typically have been subject to a judicial "hands off" policy. ${ }^{174}$

But $P$ ugh may present a different case than Rizzo, one in which the constitutional violations might particularly warrant federal adjudication and relief, ${ }^{175}$ in part because the violations are both more pervasive and more difficult to remedy. ${ }^{176}$ The Rizzo petitioners were citizens complaining of police abuses, which, although offensive and occasionally dangerous, ${ }^{177}$ did not immediately jeopardize life and limb. More importantly, perhaps, the citizens of Philadelphia had recourse to the ballot or, failing that, to their right to relocate to rid themselves of their tormentors. The inmates of the Alabama state prisons, on the other hand, not only lacked any potential control over, but were entirely controlled by, the objects of their complaints and could look only to the courts for relief. The Pugb standards should not be judged, then, in terms of whether any judicial intervention was called for but in terms of whether federal intervention and intervention in this particular form are the least restrictive alternatives available for dealing effectively with these abuses. If they are, then, just as in other areas of established federal court interventionism such as the school desegregation cases, ${ }^{178}$ principles of federalism may not prevent federal judicial correction of unconstitutional state action.

The striking parallels between the Pugh court's order and the one in a recent instance of federal judicial action in the desegregation area-Morgan v. McDonough ${ }^{179}$, the South Boston High School case-suggest that at

172. Sie text accompanying note 40 supra.

173. See text accompanying notes $145-70$ supra.

174. See text accompanying notes 44-45 supra.

175. Cf. Steffel v. Thompson, 415 U.S. 452, 464 (1974); Mitchum v. Foster, 407 U.S. 225, 242 ( 1972 ) (federal courts are primary fora for vindicating federal civil rights).

176. The need for federal relief may be especially powerful in cases involving massive challenges to statewide prison systems that often result in high state officials being named as defendants. See text accompanying note 12 supra. Moreover, because local, often elected, judges might fear the political obloquy associated with such remedies as closing down prisons or ordering the expenditure of more public resources on them, and, by virtue of their sentencing authority, might have an institutional concern for not rocking the state's penal boat, they may not provide as adequate an alternative source of judicial protection. See generally Bartels, supra note 34 , at 30 n.9.

177. Council of Orgs. on Phila. Police Accountability and Responsibility v. Rizzo, 357 F. Supp. I 289, I 294 n.316 (E.D. Pa. I973), aff'd sub nom. Goode v. Rizzo, 506 F.2d 542 (3d Cir. I974), rev'd, $4^{23}$ U.S. 362 (1976). The district court made findings of fact concerning over 30 allegations of specific instances of misconduct by the police.

178. See, e.g., note 31 supra; notes $179-85$ infra and accompanying texts.

179. 540 F.2d 527 (Ist Cir. 1976), cert. denied, 97 S. Ct. 743 (1977). 
least in some cases a relatively intrusive form of intervention in state prison systems is equally necessary in state school systems. ${ }^{180}$ In affirming the district court's decision to place the school in receivership, the First Circuit Court of Appeals in Morgan noted the lack of cooperation given by school officials to the court's initial desegregation order. ${ }^{181}$ Similarly, in 1972 , the Federal District Court for the Middle District of Alabama had entered a detailed decree ordering that Alabama prisoners be provided adequate medical care. ${ }^{182}$ Yet 4 years later, the $P$ ugh court noted that 70 percent of the prison population required some kind of psychiatric treatment and that "nothing has been done to alleviate this situation." 183 The two cases also resemble each other in terms of the actual remedies chosen in response to their similar histories of noncompliance with constitutional dictates. In Morgan, the court of appeals warned that "the principal alternative to the receivership order was to order that South Boston High be closed." 184 Chief Judge Johnson in Pugh also saw closing the prisons as the principal alternative to dictating the standards under which the prisons may continue to operate. ${ }^{185}$

The crux of this aspect of the problem, then, is whether that assessment was correct, or whether some less intrusive measure might have rectified that situation as well. The most obvious solution, of course, is the traditional order to state officials to draft a plan for improving conditions in the state institutions. ${ }^{186}$ Although a plan of this type was invalidated in Rizzo, such a plan has fewer federalism deficiencies than the more intrusive $P u g b$ and Morgan approaches because it leaves state personnel considerable control. It also comports better with the policy behind the "hands off" doctrine by relying on the presumed expertise of local prison adminis-

I80. Education, no less than the police affairs involved in Rizzo and the prison affairs involved in Pugh, see text accompanying note 174 supra, is an area of traditional state supremacy and discretion. See Pierce v. Society of Sisters, 268 U.S. 510, 534 (1925); Meyer v. Nebraska, 262 U.S. $390,402-03$ (1923).

I 8 I. 540 F.2d at 533-34. The litigation has been protracted indeed. In 1974, the School Committee was enjoined from discriminating on the basis of race in the operation of the Boston Public Schools and was ordered to formulate and implement plans to secure the plaintiffs' constitutional rights. Morgan v. Hennigan, 379 F. Supp. 4 IO (D. Mass.), aff'd, 509 F.2d 580 (Ist Cir. 1974), cert. denied, 42 I U.S. 963 (1975). This order was augmented by one concerning faculty hiring practices, Morgan v. Kerrigan, 388 F. Supp. 58I (D. Mass. 1975), aff'd, 530 F.2d 43I (Ist Cir. 1976), another concerning the desegegation plan, Morgan v. Kerrigan, 40I F. Supp. 216 (D. Mass.), stay of implementation pending appeal denied, 42 I U.S. $96_{3}$ (1976), and a third placing a public high school in receivership, Morgan v. Kerrigan, 409 F. Supp. I I 4 I (D. Mass. 1975), aff'd sub nom. Morgan v. McDonough, 540 F.2d 527 (Ist Cir. 1976), cert. denied, 97 S. Ct. 743 (1977).

I82. Newman v. Alabama, 349 F. Supp. 278 (M.D. Ala. I972).

I83. 406 F. Supp. at 324 .

r 84.540 F.2d at 534 .

I85. 406 F. Supp. at 331 .

186. See note 139 supra and accompanying text. 
trators rather than inexpert federal judges. ${ }^{187}$ Nonetheless, having achieved the disappointing results noted above in using this approach in attacking inadequate medical care in the Alabama prisons, ${ }^{188}$ Chief Judge Johnson was justified in rejecting it in $P u g h$. Moreover, by establishing the Human Rights Committee, he actually adopted an intermediate approach that still leaves much of the supervision and implementation of the decree in the hands of local officials ${ }^{189}$ while laying down specific guidelines that must be met. Given Chief Judge Johnson's unsatisfactory experience with the less intrusive approach of reliance on Alabama prison officials, the Human Rights Committee provides an imaginative and workable accommodation between the principles of federalism and the need for protection of constitutional rights.

The Human Rights Committee also helps answer the related lack-ofexpertise objection to federal judicial intervention in prison affairs. The order in $P u g h$ ensured the Committee a qualified staff ${ }^{190}$ and authority to "engage and consult appropriate, independent specialists." 191 To be sure, the formation and functioning of such a panel may prove to be unwieldy and expensive in practice. But when the situation requires continued oversight to guarantee compliance with the court order, an expert committee composed of members of the local community surely must be preferable to a lone federal judge with little or no experience in prison administration.

Furthermore, the federal intervention in Pugb seems just as proper as the dramatic form of its intervention, because prison officials in such states as Alabama have failed consistently to carry out their eighth and I4th amendment obligation to eschew cruelly and unusually punishing the inmates in the prisons they control. ${ }^{192}$ Try as they might, state officers constitutionally may not hide behind the federalism principles in Rizzo or

I87. See, e.g., Muniz v. United States, 305 F.2d 285, 287 (2d Cir. 1962) (Kaufman, J., dissenting) (" $[T]$ he decision in this case will force the lower courts to substitute their judgment of what constitutes 'reasonable' behavior in the delicate area of prison administration for that of the persons charged by statute with the duty of running our correctional system."); notes $4^{\mathrm{r}-53}$ supra and accompanying text.

188. See note i 6 supra.

189. Among the Committee members were representatives of the clergy, the professions and academia. See 406 F. Supp. at 336-37.

190. Sce note I5I supra and accompanying text.

I91. 406 F. Supp. at 331-32.

192. The $14^{\text {th }}$ amendment, which underlies most of the litigation discussed in this Article, forbids a state to "deprive any person of life, liberty, or property, without due process of law." U.S. CONST. amend. XIV. The United States Supreme Court has interpreted this clause to require that the states fulfill most of the obligations towards citizens that the Bill of Rights imposes on the federal government. See Duncan v. Louisiana, 39r U.S. 145, 147-58 (1968). This requirement on the states includes the cruel and unusual punishment clause of the eighth amendment. See Robinson v. California, 370 U.S. 660, 666 (I962). 
even in the Ioth amendment ${ }^{193}$ to avoid this or any other "obligation imposed upon them by the Constitution of the United States," 194 nor "to frustrate or ignore the mandates of the Constitution." 195 It is precisely in such circumstances as these that the federal courts must serve as the " "primary and powerful reliances for vindicating every right given by the Constitution, the laws and treaties of the United States." "196 In the words of one federal appellate judge:

I look forward to the day when the State and its political subdivisions will again take up their mantle of responsibility . . . and thereby relieve the federal Government of the necessity of intervening in their affairs. Until that day arrives, the responsibility for this intervention must rest with those who through their ineptitude and public disservice have forced it. ${ }^{197}$

193. Yet state officials frequently have proffered the Ioth amendment's residuum of state powers as a defense to the exercise of federal jurisdiction over actions alleging state violations of federal constitutional rights. See Johnson, The Constitution and the Federal District Judge, 54 TEx. L. REv. 903, 914 (1976) (article by Chief Judge Johnson).

194. Id. (emphasis deleted).

195. Id.

196. Steffel v. Thompson, 4I5 U.S. 452, 464 (1974) (opinion for the Court by Justice Brennan), quoting F. Frankfurter \& J. LANDIS, THE Business of THE SUPREME COURT 64 (1928). But see Brennan, State Constitutions and the Protection of Individual Rights, 90 Harv. L. REv. 489 (1977).

Monroe v. Pape, 365 U.S. 167 ( 1961 ), provided that complaints against state agencies under 42 U.S.C. $\$ 1983$ (1970) generally could be prosecuted without prior resort to a state judicial remedy, unless the state has commenced or is about to commence on its own criminal or quasicriminal action against the federal complainant. See, e.g., Huffman v. Pursue, Led., 420 U.S. 592 (1975); Younger v. Harris, 401 U.S. 37 (I97I). See generally Bartels, supra note 34 . Dicta in Rizzo v. Goode, 423 U.S. 362 (1976), however, suggest that the scope of relief obtainable from the federal courts against state officials may be narrower than that available in state courts. Id. at 378-80. Although the principles of federalism discussed in Rizzo may aggravate problems of judicial intervention, they caution federal restraint, and qualify the broad holding in Monroe, at the very least, only when adequate relief is available from state courts dedicated to upholding and enforcing the eighth amendment. See Monroe v. Pape, 365 U.S. I67, I 74 ( 1961 ) (purpose of Congress in enacting $\$$ I983 was "to provide a federal remedy where the state remedy, though adequate in theory, was not available in practice"). In light of the persistent failure of many states' courts to face up to the eighth amendment problems inherent within the prison systems of those states, the basic prerequisite for federal restraint is unfulfilled in prison conditions cases.

197. Dent v. Duncan, 360 F.2d 333, 337-38 (5th Cir. I966) (Rives, J., concurring specially); see Mason, Judicial Activism Old and New, 55 VA. L. Rev. 385, 408 (I969); of. American Bar association Project on Minimum Standards for Criminal Justice, Standards Relating to Post-Conviction Remedies 2 (Approved Draft, ig68) (improved state postconviction remedies would help alleviate federalism problems caused by current need to resort to federal habeas corpus for relief). One commentator has written in terms of the realities of our political process that "the Alabama Federal Intervention Syndrome . . . is the tendency of many state officials to punt their problems to the federal courts. Many federal judges have grown accustomed to allowing state officials to make political speeches as a prelude to receiving the order of the district court. This role requires the federal courts to serve as a buffer between the state officials and their constituencies, raising the familiar criticism that state officials rely upon the federal courts to impose needed reforms rather than accomplishing them themselves." McCor- 
Two other criticisms of federal judicial action often characterize federalism attacks on judicial interventionism: that such activism encourages potential inmate-plaintiffs to add their cases to already overburdened federal court dockets ${ }^{198}$ and that it discourages activity by legislators who arguably are more qualified to achieve systematic prison reform. ${ }^{199}$ The methods adopted by the Pugh court actually turn these supposed disadvantages of interventionism into advantages in the context of prison condition litigation by fostering judicial economy and providing an incentive for state officials to begin prison reform themselves.

By addressing unconstitutional conditions of confinement cumulatively and by employing committees to supervise their orders, the federal courts could function without unduly encumbering their time and energies. Traditionally, the courts have relied on case-by-case adjudication of individual prisoner complaints and on remedies limited to a particular plaintiff and very specific constitutional imperfections, in order to accomplish eighth amendment goals. But recently these complaints have accelerated in number beyond easily manageable levels. ${ }^{200}$ By following the $P$ ugh approach, however, courts can order a comprehensive program for remedying the totality of unconstitutional conditions. A Human Rights Committee, moreover, can provide an ongoing forum for inmate grievances without directly burdening the judicial process. ${ }^{201}$ Such a committee might even offer a remedy mechanism for the investigation and disposition of the claims of those prisoners who prefer to petition the court for redress. ${ }^{202}$

mack, The Expansion of Federal Question Jurisdiction and the Prisoner Complaint Caseload, 1975 WIS:L. REv. 523, 536 (foornotes omitted). See Sostre v. McGinnis, 442 F.2d I78, 205 (2d Cir. 197 I) (en banc), cert. denied, 404 U.S. I049, 405 U.S. 978 (1972).

198. Set generally McCormack, supra note 197 .

I99. See L. Goldberg \& E. Levenson, LaWless Judges 9-Ii (1935); Bickel, Is the Warren Court Tao "Political"?, in The SuPREME COURT UNDER EARL WARREN $216,218-19$, $221-22$ (L. Levy ed. 1972), reprinted from N.Y. Times, Sept. 25, 1966, $\$ 6$ (Magazine), at 30.

200. Ser generally McCormack, supra note 197. Typically, these complaints are instituted without the assistance of counsel. For a discussion and analysis of post-conviction pro se litigation, see Flannery \& Robbins, The Misunderstond Pro Se Litigant: More than a Pawn in the Game, 4I BrookLYN L. REv. 769 (1975); Robbins \& Herman, supra note I 15; Zeigler \& Hermann, The Intisible Litigant: An Inside View of Pro Se Actions in the Federal Courts, 47 N.Y.U. L. ReV. I57 (1972).

201. Commentators have argued that informal and ongoing dispute solving mechanisms may have advantages over traditional judicial hearings in solving certain types of disputes, including, for example, those between students and teachers. See, e.g., Kirp, Proceduralism and Burcaucracy: Due Process in the School Setting, 28 STAN. L. Rev. 84I, 864-70 (1976). Nonetheless, some inmates, of course, would wish to go directly to court, perceiving it as "the one institution specifically designed for the vindication of the individual's constitutional rights." Flannery \& Robbins, supra note 200 , at $77 \mathrm{I}$. But the availability of another forum would reduce the burden on the federal courts at least to some extent.

202. "[O]ne of the most effective methods of attaining standards and achieving goals is to add to them mechanisms for their enforcement." NATIONAL Advisory Commission ON Crimi- 
The activist trend of judicial supervision manifested in $P u g h$ also should induce legislative and administrative action to remedy undesirable conditions of prison confinement. The Governor of Missouri, for example, recently signed into law legislation increasing state payments to county jail facilities, because "[f]ederal court decisions in Missouri have made it clear that under our United States Constitution certain jail standards must be met; otherwise, the courts may order necessary changes."203

In sum, despite the precariousness of its constitutional bases and the enormity of its federal judicial involvement in state penal affairs, the remedy afforded in Pugh $v$. Locke represents a well-conceived and least intrusive means of effectively bringing a degree of order, sanitation, rehabilitation, and basic livability to state prisons. Moreover, that remedy may serve as the only means of effectively enforcing the eighth amendment's ban on cruel and unusual punishment as embodied in the developing "totality of prison conditions" doctrine. Because that doctrine, in turn, provides the only viable analytical approach to assuring that prison confinement - the most common punishment meted out to serious offenders by the states' criminal justice systems-is not cruel and unusual, the Pugh remedy may follow inexorably from a commitment seriously to pursue the mandate of the eighth amendment in the prison setting.

\section{CONCLUSION}

The uniqueness and importance of Chief Judge Johnson's decision in Pugh v. Locke, as well as its uncertain precedential value, lie in its unabashed willingness to carry eighth amendment doctrine and federal

NAI JUSTICE STANDARDS AND GOALS, supra note 170, at 5; see note 140 supra and accompanying 'text.

203. Kansas City Star, June 23, 1976, at 3A, col. 3. See id., May 3I, 1976, at I8, col. I I (discussing Pugh decision); of. Comment, Judicial Activism in Tort Reform: The Guest Statute Exemplar and a Proposal for Comparative Negligence, 2 I U.C.L.A. L. REv. 1566, 1592-94 (1974) (judicial activism is proper where legislative action is unlikely due to the lack of any "articulate pressure group").

Of course, federal court instigation of state penal reform provides no guarantee that changes will be either substantive or permanent. For example, 5 years after the original Holt v. Sarver case, 300 F. Supp. 825 (E.D. Ark. 1969), supplemented, 309 F. Supp. 362 (E.D. Ark. 1970), aff'd, $44^{2}$ F.2d 304 (8th Cir. 197I), the Eighth Circuit Court of Appeals unanimously reversed in part a lower court order releasing the Arkansas prison system from active judicial supervision, stating: "Based on the overall record before us, it is our firm conviction that the Arkansas correctional system is still unconstitutional. We are fully cognizant of the considerable progress which has been made by the Board of Correction with the minimal resources at hand. However, we confront a record and factual history of a sub-human environment in which individuals have been confined under the color of state law. The effort to make some amelioration of those conditions will simply not suffice." Finney v. Arkansas Bd. of Correction, 505 F.2d 194, 215 (8th Cir. 1974) (emphasis in original). 
remedial involvement in state penal affairs far beyond the traditional bounds of conditions-of-confinement adjudication. ${ }^{204}$ By that willingness, Pugh v. Locke challenges traditional views of the legal system itself: that the federal judiciary should not participate in what are essentially state affairs $^{205}$ and that judges should hesitate to make decisions that call for political judgments ${ }^{206}$ or administrative expertise. ${ }^{207}$ But, as the preceding analysis argues, even these principles occasionally must give way to the reality of intransigent opposition among state officials who have neglected or refused to correct unconstitutional or unlawful state policies and practices. ${ }^{208}$

The order in Pugh also challenges an even more basic tenet of the legal system that underlies the ones discussed above: that the powers of government should be separate and distinct. ${ }^{209}$ In particular, the judicial intervention exemplified by the remedy in $P u g b$ raises the question of whether taking remedial action that approaches running a state prison system is a proper role for any judiciary, state or federal. Justice Harlan neatly summed up the problem when he spoke of the role of the Supreme Court:

From the beginning . . . two views as to the proper role of the Supreme Court in . our governmental system have existed . . . .

The one [view] is that the Court should stand ready to bring about needed basic changes in our society which for one reason or another have failed or lagged in their accomplishment by other means.

The ocher [view] is that such changes are at best left to the political process and

204. Pugh is the product of one of the more liberal and creative judges on the federal bench. Chief Judge Johnson's proclivity for establishing minimum constitutional standards is evident in other areas of the law. These areas include the operation and management of the facilities maintained by the Alabama Department of Mental Health for the mentally ill and mentally retarded, Wyatt v. Stickney, 325 F. Supp. 781 (M.D. Ala. I97 I), enforced, 344 F. Supp. 373 and 344 F. Supp. 387 (M.D. Ala. I972), modified sub nom. Wyatt v. Aderholt, 503 F.2d I305 (5th Cir. 1974) (affirming constitutional "right to treatment"), and the operation and management of medical care facilities available to prisoners in the Alabama penal system, Newman v. Alabama, 349 F. Supp. 278 (M.D. Ala. I972), aff'd in part, 503 F.2d 1320 (5th Cir. 1974), cert. denied, 42 I U.S. 948 (1975), discussed in note I 16 supra. For an interesting biographical article on Judge Johnson, see Wall St. J., Apr. 15, 1976, at I, col. I.

205. See U.S. ConST. amend. X: "The powers not delegated to the United States by the Constitution, nor prohibired by it to the States, are reserved to the States respectively, or to the people."

206. See, e.g., Marbury v. Madison, 5 U.S. (I Cranch) I37, I70 (1803). But see Eakin v. Raub, I2 Serg. \& Rawl. 330, 348 (Pa. I825) (Gibson, J., dissenting); A. DE TocQueville, DEMOCRACY IN AMERICA 280 (P. Bradley ed. 1945) ("[S]carcely any political question arises in the United States that is not resolved, sooner or later, into a judicial question.").

207. See, e.g., Brotherhood of Locomotive Firemen v. Chicago, R.I. \& P.R.R., 393 U.S. 129, 136-37 (1968); notes 45, 69 supra and accompanying texts. Chief Judge Johnson expressed this view in Johnson, supra note 193 .

208. See, e.g., notes $x 8 \mathrm{I}-83$ supra and accompanying text.

209. See The Federalist Nos. 47,48 (J. Madison). 
should nor be undertaken by judges who, as they should be because of their office, are beyond the reach of political considerations. . . 210

This admonition that courts should avoid the "political thicket"211 comes too late, however, for constitutional courts have been firmly entrenched in that sphere since Marbury v. Madison. ${ }^{212}$ Chief Justice Marshall himself stated that he did not want to be remembered either for having sought "to enlarge the judicial power beyond its proper bounds" 213 or for having "feared to carry it to the fullest extent duty required."214

The question then becomes one of defining the proper bounds of judicial activity as determined by the "duty required." Surely the duty to interpret and enforce the Constitution looms large in the obligations of all courts, state or federal. ${ }^{215}$ But that calls for some degree of certainty about

2 10. U.S. NEWS \& WORLD REPORT, Dec. I8, 1967, at 36. Rather dolefully, Justice Harlan's speech at Princeton University concluded that "[ $t]$ here can be little doubt but that the former, broader role of the [federal courts] is the one currently in vogue, and that it is resulting in the accomplishment of basic changes in governmental relationships . . . Id.

2 I I. See Colegrove v. Green, 328 U.S. 549, 556 (r946) (Frankfurter, J., concurring).

212. 5 U.S. (I Cranch) I37.(1803) (Marshall, C.J.). See Mason, stpra note 197, at 386. This aspect of the courts' decisionmaking is not free of criticism, of course. One interesting source of commentary on judicial activism is the judiciary irself, usually in dissenting opinions, even though "[e]very Justice has been accused of legislating and everyone has joined in that accusation of others." R. JACKSON, The SUPREME COURT IN THE AMERICAN SYSTEM OF GOVERNMENT 80 (1963). See, e.g., Teleprompter Corp. v: Columbia Broadcasting System, Inc., 415 U.S. 394, 419 (1974) (Douglas, J., dissenting) ("The [Court's] result reads the Copyright Act out of existence. . . That may or may not be desirable public policy. But it is a legislative decision that not even a rampant judicial activism should entertain."); United States v. Wade, 388 U.S. $218,250(1967)$ (Black, J., dissenting in part) ("I . . . feel that we are deciding what the Constitution is, not from what it says, but from what we think it would have been wise for the Framers to put in it. That to me [is] 'judicial activism' at its worst.").

213. Letter from John Marshall to Joseph Story, October I2, I831, quoted in $4 \mathrm{~A}$. BEVERIDGE, THE LIFE OF JOHN MARSHALl 522 (I919).

214. Id.

21 5. See, e.g., Marbury v. Madison, 5 U.S. (I Cranch) 137, I77 (I803) (Marshall, C.J.) ("[I] $\mathrm{r}$ is emphatically the province and duty of the judicial department to say what the law is."); United States v. Nixon, 418 U.S. 683, 703-05 (1974); Speech of Chief Justice Hughes before the Elmira Chamber of Commerce, Elmira, N.Y., May 3, 1907, in C. Hughes, AdDresses of Charles Evans Hughes 1906-1916, at 179, I85 (2d ed. 1961) ("[T] the judges say it is"). In Weems v. United States, 217 U.S. 349 ( 1910 ), an eighth amendment cruel and unusual punishment case, see notes 58-59 supra and accompanying text, the Supreme Court stated: "The function of the legislature is primary, its exercises fortified by presumptions of right and legality, and is not to be interfered with lightly, nor by any judicial conception of their wisdom or propriety. They have no limitation . . . but constitutional ones, and what those are the judiciary muse judge." Id. at 379 .

The judge's power and duty to interpret and enforce the law is also the power and duty to create it. Traynor, Lau' and Social Cbange in a Democratic Society, 1956 U. ILL. L.F. 230, 232 ("[C]ourts have a creative job to do when they find that a rule has lost its touch with reality and should be abandoned or reformulated to meet new conditions and new moral values."). Contrary to the theoretical aspirations of some preeminent jurisprudents, see, e.g. , Hart, The Supreme Court, 1958 Term, Foreuard: The Time Chart of the Justices, 73 HARv. L. REv. 84 (1959); Pollack, Racial 
just what the Constitution requires. As noted above, ${ }^{216}$ the concept of "cruel and unusual punishment" is a difficult and changing one. On the one hand, its definition might better be left to the legislators, who are, after all, duly elected and presumably in closer touch with contemporary definitions of "cruelty." On the other hand, the eighth amendment arguably was intended to guard against precisely this sort of popular sovereignty that so easily may lead to excesses against a disfavored few. But the question is moot in cases like $P u g h$, in which prison conditions prompt admissions of unconstitutionality from all who review them, including the state's own defense counsel. ${ }^{217}$ Unfortunately, many other state prison systems have not yet reached the point where the initial determination of unconstitutionality is in much dispute. In such states, the question of who should interpret the terms of the eighth amendment is considerably less important.

Given a finding of unconstitutionality, some individual or group of individuals must develop and implement a remedy. Again, some question arises as to the branch of government best fitted for the task; in this case, the choice is between the executive and the judiciary. Courts may be wise to allow prison officials to draft their own plans, reserving a supervisory role for the judiciary. If such an attempt has been made with unsatisfactory results, ${ }^{218}$ however, courts may have no alternative but to devise the plans themselves. In sum, the question of whether any court should intervene in the administration of a penal system may be answered by default.

Resolution of the questions presented by Pugh v. Locke will be difficult. Terms like "equilibrium," "duty," "rights," and "proper bounds" come easily and frequently to mind, but they are less easily and certainly less frequently defined. ${ }^{219}$ The Pugh approach comes down on the side of

Discrimination and Judicial Integrity: A Reply to Professor Wechsler, 108 U. PA. L. REv. I (1959); Wechsler, Tourard Neutral Principles of Constitutional Law, 73 HARv. L. REv. I (r959), there can be no constitutional interpretations in a system of logic that "has no value for its own sake." $A$. Cox, The WarRen Court: Constitutional DeCision as aN INSTRUMENT OF REFORM 22 (1968); see Miller \& Howell, The Myth of Neutrality in Constitutional Adjudication, 27 U. CHI. L. REV. 66r (1960). Because the law deals with human conduct, it must meet changing and changeable human needs and expectations. See A. Cox, supra at 22. Even the Supreme Court has recognized the extreme mutability of supposedly immutable truths, writing that "[ $\mathrm{r}]$ ime works changes, brings into existence new conditions and purposes," Weems v. United States, 217 U.S. 349.373 ( 1910$)$, and, in the context of the cruel and unusual punishment clause, the Court has built this malleability into the law by focusing on the "evolving standards of decency." Trop $v$. Dulles, 356 U.S. 86, ror (1958) (emphasis added).

216. See notes $64-78 \mathrm{supra}$ and accompanying text.

217. See note 14 supra and accompanying text.

2 I8. Set text accompanying notes $182-83$ supra.

219. See B. Cardozo, The Nature of THE Judicial Process 28 (I92 I) ("[N]othing is stable. Nothing is absolute. All is fluid and changeable. There is an endless 'becoming.' "); Robbins, The Admissibility of Social Science Evidence in Person-Oriented Legal Adjudication, 50 IND. L.J. 493, 508-16 (1975). 
sweeping federal intervention as a last, but viable, resort. It presents public policymakers with a distinct and difficult choice: Correct unconstitutional conditions of prison confinement at significant cost to the state government ${ }^{220}$ or place the responsibility in the hands of the federal judiciary and effectively lose control over the management and resource allocation of the state prisons. Thus, Pugh $v$. Locke serves notice that unless and until the states are prepared to recognize the latent imperfections of their correctional systems, the federal courts may be compelled to take the initiative in charting the perimeters of a maturing society.

220. "The question is not whether the courts ought to intervene-they will continue to do so anyway, in some degree-but how correction[s] can strengthen its position against undesirable expansion of court supervision. If the profession evaluates itself candidly, shapes its practices to accord with the highest standards of fairness in its own tradition, and succeeds in communicating the reasons for its practices and the constructive approach being taken, the chances are great that courts will generally leave to correction[s] the freedom of action that has always been its hallmark." Kimball \& Newman, Judicial Intervention in Correctional Decisions: Threat and Response, ${ }_{4}$ CRIME \& Deline. I, I3 (1968). 